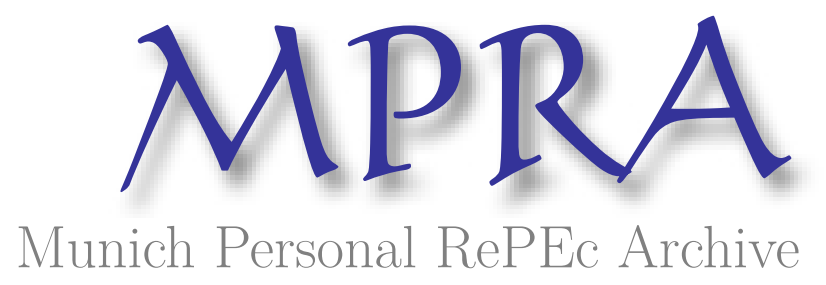

\title{
International Differences in Wage Inequality: A New Glance with European Matched Employer-Employee Data
}

\author{
Hipolito, Simon \\ EU-LEED Project
}

2008

Online at https://mpra.ub.uni-muenchen.de/7932/

MPRA Paper No. 7932, posted 26 Mar 2008 10:11 UTC 


\title{
International Differences in Wage Inequality: A New Glance with European Matched Employer-Employee Data*
}

\author{
Hipólito Simón \\ Universidad de Alicante
}

\begin{abstract}
Using unique international harmonized matched employer-employee microdata from the European Structure of Earnings Survey for nine representative European countries, this comparative study examines the origin of international differences in wage inequality. Our novel evidence uncovers that global wage inequality is highly correlated with the magnitude of inter-firm wage differentials and that workplace- and job-related factors generally have a more significant impact on within-country wage inequality than individual characteristics. On the whole, European countries exhibit considerably different wage structures: they differ significantly not only in the extent of wage inequality but also in the relative influence of factors shaping wage inequality. Comparative analyses reveal that although cross-country differences in labour force composition play a part in the explanation, differences in distribution and, very specially, in labour market prices of workplace and job characteristics are primary reasons contributing to international differences in wage inequality.
\end{abstract}

Keywords: Wage inequality; matched employer-employee data.

Journal of Economic Literature Classification Numbers: J30, J31.

\section{Introduction}

Wage inequality is an outstanding feature of labour markets. On the one hand, it influences fundamental questions such as the economics incentives to skill acquisition by workers. On the other hand, it is a major determinant of disparities in living standards. As a matter of fact, the extent of wage inequality is strongly correlated in the OECD countries with the incidence and persistence of low-wage employment and, consequently, of poverty (OECD, 2004). Thus, unsurprisingly, considerable attention has been focused in the economic literature in recent years on the origin of wage inequality, its changes over time and its international differences (for authoritative reviews, see Blau and Kahn, 1999 and Katz and Author, 1999).

Wage inequality exhibits a large international heterogeneity (for detailed descriptive evidence for the OECD members and a wide set of European economies see OECD, 2007 and Eurostat, 2005, correspondingly). A growing body of comparative labour market research has attempted to

\footnotetext{
* This work benefits from funding support of the project European Labour Market Analysis using Firm-level Panel Data and Linked Employer-Employee Data financed by the European Union under the VI Framework Programme. I acknowledge Eurostat and the National Statistical Offices of Italy, Spain, Portugal, the Netherlands, Norway, the Czech Republic, Latvia, Lithuania and Slovakia for data access to their national samples of the European Structure of Earnings Survey 2002. In order to fulfill data protection and confidentiality restrictions the research has been conducted through online remote access (LISSY System) to the microdata. I am grateful to Tanvi Desai for excellent technical support with the LISSY remote system and to David Marsden, Claudio Lucifora, Ana Cardoso, Tor Eriksson and the rest of participants in the project for helpful comments. The usual disclaimer applies. E-mail: $\underline{\text { hsimon@,ua.es }}$
} 
disentangle the origin of these persistent observed international differences in wage inequality. In one of the seminal contributions, Blau and Kahn (1996) tried to explain why wage inequality is substantially higher in the United States than in other developed countries. Their findings revealed that though differences in measured characteristics of workers explain some of the considerably higher levels of male wage inequality in the United States relative to nine other OECD countries, higher wage returns to observed individual characteristics and, very specially, greater residual inequality in that country are outstanding factors. On the basis that labour market skills may differ even among workers with the same observed human capital, later studies have taken additionally into account the role of cognitive skills in shaping international differences in wage inequality. Related evidence shows, yet, that greater dispersion of cognitive ability in the United States plays just a small part in explaining higher U.S. wage inequality relative to other developed countries, so that higher labour market prices and greater residual inequality remain as quantitatively considerably more important factors in the explanation (Blau and Kahn, 2005 and Devroye and Freeman, 2002).

Given the role played by differences in labour market prices of individual characteristics in explaining international differences in wage inequality, comparative labour market research has also focused on alternative hypotheses to population heterogeneity for their elucidation. More specifically, two additional explanations have been put forward for these differences, namely the role of market forces and international differences in labour market institutions. According to explanations emphasizing market forces focus, relative wages of low skilled workers should be lower in those countries with a more abundant net supply of this kind of workers. Empirical evidence regarding this issue is rather mixed, yet. Hence, although international variation in supply and demand measures based on skill indices constructed using usual human capital indicators such as education and potential experience do not move in the right direction for explanations emphasizing market forces to provide a believable explanation (Blau and Kahn, 1996), some evidence of consistency with a supply and demand explanation of wage differentials by skill is obtained when skill is measured by cognitive tests (Leuven et al., 2004), which suggests that supply and demand may actually play a role in explaining international differences in wage returns.

In turn, institutional explanations hypothesize that institutions such as collective bargaining and minima wage regulations compress wage differentials at the bottom of the distribution in countries with centralized wage-setting systems compared to countries with decentralized systems. Industrial relations system can affect wage inequality through several routes, such as wage differentials between union and non-union workers; less dispersion in union wages, very specially at the bottom of the wage distribution, and extension and/or 'voluntary' imitation of terms of collective agreements to non-union workers (for more details, see Blau and Kahn, 1996). The major 
impact of labour institutions on wage inequality tends to be generally accepted as an uncontroversial issue, whereas the impact of labour institutions on differences in aggregate economic performance across countries remains a matter of debate (see, for instance, Freeman, 2007 and OECD, 2004). This institutional hypothesis is consistent with the evidence of Blau and Kahn (1996) that considerably higher levels of male wage inequality in the United States relative to other developed countries primarily reflect substantially larger dispersion at the bottom of the distribution. These authors also present a variety of evidence that labour market institutions, and in particular collective bargaining, are the most persuasive explanation for the observed differences between the United States and other countries, including negative correlations between a standard measure of wage centralization and overall wage dispersion and the 50-10 wage differential, respectively.

Overall current evidence reveals, therefore, that although differences in population heterogeneity across countries can contribute to our understanding of varying levels of wage inequality, they explain in practice only a minor part of international differences in inequality, regardless of whether they are measured by human capital endowments and/or cognitive skills. It also suggests that both institutions and market forces may play a role in explaining international differences in wage returns to individual characteristics and, hence, in wage inequality, although it is not sufficiently informative on their relative contributions. Yet, it should be noted that the significant part played by residual inequality in shaping cross-country differences in earnings inequality implies that the bulk of their origin is largely unknown.

This study is concerned with examining the origin of cross-country differences in wage inequality for a set of nine representative European countries on the basis of international harmonized matched employer-employee microdata drawn from the 2002 wave of the European Structure of Earnings Survey. Wage inequality exhibits a remarkable heterogeneity across Europe, which makes the examination of the origin of international differences in wage inequality across European countries particularly appealing. Let us also notice that the use of the European Structure of Earnings Survey matched microdata is a main advantage relative to previous studies on the origin of international differences in wage inequality, essentially based on microdata drawn from questionnaires to individuals or households, usually characterized by a high risk of measurement error in self-reported wages and a rather limited information on wage-determining characteristics of individuals and, very specially, of their workplaces and jobs.

The recent worlwide burgeoning development of matched employer-employee data has allowed fundamental advances in our understanding of labour markets and, specially, of wage determination (for reviews, see Hamermesh, 2007, Abowd and Kramarz, 1999 and Haltiwanger et al., 1999). Due to the availability of this type of data there exists, in particular, overwhelming evidence 
for numerous countries that different firms pay observationally similar workers different wages (for a recent review of this empirical literature see Lane, 2008), so that wage differences between firms hold a strong influence both in the levels of wage inequality (see, for example, Davis and Haltiwanger, 1991 for the United States and Cardoso, 1999 for Portugal) and in the changes of wage inequality over time (e.g. Nordström-Skans et al., 2007 for Sweden, Aagard et al., 2007 for Denmark or Dunne et al., 2004 for the United States). Current evidence suggests, furthermore, that the magnitude of inter-firm wage differentials may vary significantly across countries (Simón, 2005). On the whole, this implies that there is empirical plausibility to the argument that international differences in inter-firm wage differentials may play a part in the explanation of differences in wage inequality across countries. Notwithstanding, this is a heretofore largely untested question, which is plausibly explained by the fact that international databases with matched data are extremely scarce. ${ }^{1}$ For that reason, this sort of data has been used heretofore essentially in analyses for individual countries, despite the strong interest in their potential use for international comparisons (e.g. see Lazear and Shaw, 2007). The use in this study of the European Structure of Earnings Survey harmonized matched data permits, thus, to extend previous studies to re-examine the origin of international differences in wage inequality in a novel, more comprehensive fashion. These data allow to consider the influence of a wider set of wage-determining factors than microdata coming from individual or household surveys and, in particular, to shed light on the issue whether international differences both in the wage returns and in the distribution of workplace and job characteristics are relevant sources behind international differences in wage inequality.

In the empirical work below, the origin of within-country levels of wage inequality is firstly examined by means of the decomposition technique developed by Fields (2003). This technique provides an exact decomposition of a country's overall level of wage inequality based on the contributions of wage-determining factors, so that it allows evaluating systematically the relative contribution of each separate factor to inequality. After that, an adaptation of the Fields (2003) technique is employed in order to analyse the sources of international differences in wage inequality. Then, in order to provide a richer picture of cross-country differences in wage inequality, the decomposition methodology recently developed by Yun (2006) is used, additionally, in this part of the empirical analysis. This technique is a synthesis of the methodologies of Fields (2003) and the

\footnotetext{
${ }^{1}$ As far as we know, the only international matched employer-employee data currently available is, indeed, the European Structure of Earnings Survey. However, accessibility to their microdata has been traditionally highly constrained by data confidentiality. Consequently, this survey has been used basically for descriptive analyses (e.g. Eurostat, 2005), with the exception of a number of international comparative studies carried out with the 1995 wave of the survey in the context of a former project financed by the European Commission under extremely restrictive conditions of access to the microdata (inter alia, Lallemand et al., 2007, Plasman et al., 2007 and Simón, 2005): $5^{\text {th }}$ framework project 'Pay Inequalities and Economic Performance' (http://cep.lse.ac.uk/piep).
} 
full-distributional accounting method devised by Juhn et al. (1993). Yet, in contrast with the technique of Fields (2003), whose results are informative of the gross contribution of each single explanatory factor, it allows to release the gross contribution of each factor in two parts, explained in terms of the differences between countries in the price and the endowment, respectively, of the factor. Therefore, it permits to compute both aggregate and detailed decompositions of international differences in wage inequality distinguishing between price and endowment effects. This is particularly relevant insomuch each variable can contribute to international differences in global inequality through cross-country differences both in its remuneration and in its distribution, and, very specially, given the interest of this research in assessing the isolated effect of individual, workplace- and job-related factors.

A major finding of the study is that the magnitude of inter-firm wage differentials is strongly correlated with global wage inequality across European countries. Thus, consistent with this result, although workforce characteristics play a non-negligible influence, total wage inequality is generally more strongly associated in every European country to workplace and job attributes. Nevertheless, the particular influence on wage inequality of workplace, individual and job characteristics displays significant differences across European countries and, as a result, these factors play a significant part in shaping international heterogeneity in wage inequality. Comparative analyses confirm, in particular, the finding of previous studies that international differences in labour force composition play some influence on international differences in wage dispersion. Yet, our novel evidence uncovers that workplace and job characteristics are more influential than individual characteristics in shaping international differences in wage inequality.

Also of concern is that the influence of observed characteristics in shaping international differences in wage inequality is explained comparatively more by differences in their returns whereas, in contrast, cross-country differences in their endowments are less influential. This finding suggests that it is the difference in weights placed on wage-determining factors rather than differences in the distribution of workplace, job and individual measured characteristics that best explain international differences in wage inequality. The particularly significant part played by differences in the rewards to workplace characteristics in the explanation of international differences in wage inequality suggests, furthermore, that international differences in inter-firm wage differentials are not mostly driven by differences in returns to firm characteristics and not by heterogeneity in firm populations. It is also consistent, in line with overall obtained evidence, with the hypothesis that there is more margin to interfirm wage differentials in countries with decentralized wage-setting systems.

The outline of the article is as follows. Section 2 describes the dataset and presents summary statistics on the extent of wage dispersion and the wage-setting institutions of the countries in the 
sample. Section 3 describes the methodologies used in the analysis. Section 4 examines the sources of within-country and international differences in wage inequality. Finally, Section 5 concludes.

\section{Data}

\subsection{Data Source}

The microdata used in this study are drawn from the 2002 European Structure of Earnings Survey (ESES hereafter). This dataset is a collection of national surveys conducted in member states of the European Union (as well as Iceland and Norway) according to a common methodology under the auspices of the Statistical Office of the European Communities. It provides detailed and comparable information on the level and structure of remuneration of employees, their individual characteristics and the enterprise or local unit to which they belong. This study draws on the 2002 national data samples for Italy, Spain, Portugal, the Netherlands, the Czech Republic, Latvia, Lithuania, Slovakia and a non-EU country, Norway. The ESES survey covers workplaces with more than 9 employees in sections $\mathrm{C}$ to $\mathrm{O}$ of the economic activity classification scheme NACE, ${ }^{2}$ except for Norway, Latvia, Italy and Portugal where sectors L, M, N and O (in turn, public administration, defence and compulsory social security; education; health and social work and other community, social and personal service activities) are not covered and Spain, where sector $\mathrm{L}$ is not covered and, thus, industry coverage is narrower than elsewhere. ${ }^{3}$ Let us notice that the exclusion of small entreprises may affect the figures for southern countries in particular, given that a significant portion of total private employment in these countries corresponds to this segment of the labour market.

A prominent feature of the ESES is that it consists of matched employer-employee data with a sample of workers at each workplace. The ESES collects information, usually provided by the management of the establishments, on demographic information for workers (earnings, sex, age, level of education, tenure in the firm, occupation, type of contract and full-time/part-time indicators) along with detailed information for each respondent's establishment (industry, size, type of financial control and different features of workplace's labour force composition derived from the observations of each workplace included in ESES: the ratio to all employees in the wokplace of

\footnotetext{
${ }^{2}$ The national samples of Norway, Latvia, Lithuania, the Netherlands and Slovakia actually also cover workplaces with less than 10 employees. In order to work with similar types of workplaces in all the countries, they have been dropped from the samples.

3 When samples in countries with a wider coverage are restricted to sections $\mathrm{C}$ to $\mathrm{K}$ of the NACE classification, international differences in wage inequality exhibit, with some exception, very slight changes. Thus, as a matter of fact, the variance of $\log$ hourly wages is 0.399 in Lithuania (compared to 0.385 with the sample with wider sectoral coverage), 0.271 in Spain (0.274), 0.256 in Slovakia (0.252), 0.210 in the Czech Republic (0.196) and 0.321 in the Netherlands (0.254).
} 
women, low- and high-educated workers and the average age and tenure). ${ }^{4}$ The analysis is restricted to individuals aged 18-64. The final national samples are in the range between 58,049 and 972,729 workers (for Portugal and the Czech Republic, respectively) and between 472 and 21,615 establishments (Slovakia and Spain) and the number of workers per workplace in the sample is in the range between 8.8 and 831.2 (Portugal and Slovakia). Descriptive statistics are reported in Table A.1 in the Appendix.

The earnings measure used in the empirical analysis is the gross hourly wage. Thus, the goal of the research is to explain international differences in the distribution of the price of labour rather than in labour incomes. Earnings used to calculate hourly wages concern to a 'normal' reference month and cover remuneration in cash paid by the employer before deductions for tax and employee social security contributions. They comprise all payments different from overtime pay, including commissions, travelling expenses, premium payments for shift, night and weekend work and all bonuses and allowances, regardless of whether or not they are paid regularly in each monthly pay period (thus, they also cover annual bonuses as holiday bonuses, $13^{\text {th }}$ and $14^{\text {th }}$ monthly salaries, profit sharing and allowances for leave not taken) ${ }^{5}$. Let us emphasize that the wage information in the ESES data has an important advantage in that the wage definition is exactly the same across countries.

\subsection{Descriptive Evidence}

Table 1 documents wage dispersion and the main features of wage-setting institutions of the countries in the sample. Wage dispersion shows a large heterogeneity according to different wage inequalities measures and, though the magnitudes of international differences displays slight differences, the ranking of the countries is invariant regardless of the particular inequality measures. Thus, the more dispersed wage structure is found in Latvia (where, as a matter of fact, the variance of log hourly wages is 0.529 and the ninetieth-tenth percentile log-wage differential is 1.786) and the more compressed distribution in Norway (0.136 and 0.891, respectively). Wage inequality in the remaining countries lies in between that of the two former countries, being particularly important in Lithuania (0.385 and 1.591) and Portugal (0.376 and 1.545) and, to a lesser extent, in Spain (0.274 and 1.289), Slovakia (0.252 and

\footnotetext{
${ }^{4}$ Information on the type of collective collective agreement covering the workplace is also available for some of the countries in the sample (Norway, Italy and the Netherlands are exceptions). Yet, due to the presence of different institutional wage-settings and, consequently, types of collective agreements across countries it is troublesome to design proper common indicators to all the countries. Likewise, a variable regarding the main market of the firm is available only for a small subset of countries. Information on these issues has not been used in subsequent comparative empirical analyses.

${ }^{5}$ According to ESES data, bonuses paid annually are not negligible and exhibit a remarkable cross-country heterogeneity: they represent in industry and services between 1-3\% of mean annual earnings in Norway and Lithuania, around 5\% in Latvia, 6\% in Italy and 9\% in the Netherlands and between 14-17\% in the Czech Republic, Slovakia, Portugal and Spain (Eurostat, 2005).
} 
1.190) and the Netherlands (0.254 and 1.139), and comparatively less significant in the Czech Republic (0.196 and 1.060) and Italy (0.175 and 1.002).

In order to put this evidence into a wider perspective, Table A.2 in the Appendix reports earnings dispersion for the European Union-25 countries plus Norway, as measured by the 90-10 interdecile ratio. (Although, interestingly, evidence in Table A.2 is drawn from the same survey used in this study, the 2002 wave of the European Structure of Earnings Survey, unfortunately, it does not include information on the specific earnings measure). It is confirmed that earnings inequality exhibits a very important heterogeneity across Europe: wage structures are particularly compressed in Nordic countries (the 90-10 interdecile ratio in these countries is in general around 2) whereas, on the other hand, they are particularly dispersed in some of the new member states of Central and Eastern Europe, such as Latvia, Lithuania, Slovenia, Poland and Estonia (the 90-10 interdecile ratio goes in this group of economies from 4.5 in Slovenia to 4.94 in Estonia). Very interestingly, the countries embraced by this study almost cover the full range of heterogeneity in earnings inequality in Europe. Hence, earnings disparities in Latvia and Lithuania are in the upper range of the EU countries (to be more precise, only Estonia exhibits a significantly higher wage inequality than them); earnings dispersion in Norway lies in the lower range of this group of countries, resembling other Nordic countries (actually, only Finland ranks below Norway); whereas the remaining countries are in the middle of the ranking according to the extent of inequality. An additional point to note is that the Czech Republic and Slovakia are the two new member states of Central and Eastern Europe with the lowest earnings inequality and, hence, that they do not fit with the very dispersed wage structures displayed in general by these countries. ${ }^{6}$

As emphasized in the introduction, certain labour institutions are expected to be major factors leading to more or less dispersed wage structures. In particular, a centralized collective bargaining system and a binding statutory minimum wage may generate a comparatively compressed wage structure (Blau and Kahn, 1999, Nickell and Layard, 1999). With the exception of Norway and Italy, statutory minima wages exist in all the countries in the study. Yet, they are usually set in all them in low levels by international standards (minima wages go from 33\% of the average gross wage in Spain to $45 \%$ in the Netherlands). In turn, Norway, Italy Spain, Portugal and the Netherlands display centralized systems of collective bargaining, which are usual in the 'corporatist' former European Union-15 countries. Thus, collective bargaining is conducted in Italy, Spain, Portugal and the Netherlands mainly on an industry-wide level, whereas wage-setting coordination at an economy-

\footnotetext{
${ }^{6}$ The new member states of Central and Eastern Europe witnessed a widening of the earnings distribution during their transition stages, starting from the comparatively low levels of inequality which were a feature of their former centrally planned systems. Yet, the widening of earnings distribution concentrated in the early phase of the transition, so that the trend towards greater inequality in most transitional countries tapered off during the late 1990s (Rutkoswki, 2001).
} 
wide level is specially important in Norway. Accordingly, collective bargaining exhibits in these five countries a high coverage rate (in the order of $70-80 \%$ ), with a significant coordination among the different units of negotiation. On the other hand, collective bargaining in the Czech Republic, Slovakia, Lithuania and Latvia displays a low coverage rate (14\% in Lithuania, 20\% in Latvia, 25\% in the Czech Republic and 50\% in Slovakia), is mainly conducted on a company level (with the exception of Slovakia) and the coordination among the units of negotiation is generally low (this sort of decentralized collective bargaining is also prevalent in the other new members states of the European Union of Central and Eastern Europe: EIRO, 2002).

Overall, obtained evidence for the countries in the sample offers a weak support to the hypothesis that institutional differences play a role in driving the pattern of international heterogeneity in wage inequality. Therefore, bivariate correlations across countries between the institutional indicators and the wage dispersion measures in Table 1 are systematically negative, but they are not statistically significant at conventional levels. The lowest wage inequality in the set of countries is actually found in Norway and Italy, two countries with centralized wage-setting systems, and the highest inequality corresponds to Lithuania and Latvia, with decentralized systems. Yet, evidence on the influence of institutions on wage inequality is more mixed for the remaining countries: Spain and Portugal exhibit a significantly higher wage inequality than both the Netherlands, an economy with broad institutional similarities, and the Czech Republic and Slovakia, two countries with comparatively decentralized wage-setting systems. On the other hand, it is also observed that the lower level of wage inequality in Norway and Italy reflects considerably more compression at the bottom of the distribution (hence, the 50-10 percentile log-wage differential in Norway and Italy is 0.316 and 0.398 , respectively, by far the lowest differentials of all the countries in the sample), a result which is consistent with a role for unions in 'bringing up the bottom' of the wage distribution. Nevertheless, the remaining countries exhibit (with the exception of Lithuania) a roughly similar degree of wage inequality at the left tail of the wage distribution: their 50-10 percentile log-wage differentials lie in between 0.493 and 0.747 (the coefficient of variation of the indicator for the nine countries is of $23.1 \%$ ). In contrast, international differences in wage inequality across Europe actually reflect more the influence of substantially larger differences in inequality at the top of the distribution (90-50 percentile log-wage differentials lie in between 0.544 and 1.198, with a coefficient of variation for the nine countries of $29.9 \%$ ), a result which, prima facie, does not conform to standard institutional explanations.

Additional evidence in Table 1 suggests that cross-country differences in wage dispersion in Europe are significantly related to the dispersion of workplace wage differentials. (Details of the method employed for calculating their dispersion are given in the notes of Table 1.) Thus, the 
bivariate correlation across countries between wage inequality and the magnitude of workplace wage differentials is always highly positive and statistically significant at conventional levels, regardless of the inequality measure (bivariate correlations are systematically higher than 0.9 , with the only exception noted below), although the influence of inter-workplace wage differentials in shaping wage inequality may be weaker at the bottom end of the wage distribution (thus, the magnitude of workplace wage differentials and the 50-10 percentile log-wage differential exhibit positive but nonsignificant correlations around 0.5). It has been hypothesized that there should be more scope to inter-firm wage differentials in countries with decentralized collective bargaining systems, with an emphasis on single-firm agreements, than in countries where bargaining is conducted on an industrywide level (Blau and Kahn, 1996 and Devroye and Freeman, 2002). Bivariate correlations across countries between the institutional indicator on the extent of centralization of collective bargaining and the dispersion of inter-firm wage differentials are negative (although non-significant) and considerably higher when heterogeneity in individual and job characteristics is controlled for, a finding which is consistent with the plausibility of this institutional explanation for European countries.

It should be noted, yet, that wage residual dispersion (that is, estimations of the remaining wage inequality net of the effect of inter-firm wage differentials) is positively correlated across countries with global inequality measures (see last rows in Table 1), very specially when the effect of a full set of individual and job characteristics is also controlled for (bivariate correlations are in this case significant at 10\%). Overall, this evidence suggests that, together with the influence of inter-firm wage differentials and individual and job heterogeneity, unobserved elements may also be relevant factors shaping international differences in wage inequality across European countries.

\section{Methods}

\subsection{Decomposing within-country wage inequality levels: the Fields (2003) methodology}

As noted in the introduction, the first part of the empirical analysis consists of an examination of the determinants of the levels of inequality in each country by applying the technique developed by Fields (2003). This methodology is based on regression analysis, and departs from the OLS estimation of a semilogarithmic individual wage equation. Suppressing individual subscripts for ease of presentation, the equation is of the form:

$$
w^{A}=\beta_{0}^{A}+\sum_{k=1}^{K-1} \beta_{k}^{A} X_{k}^{A}+\varepsilon^{A}
$$


where $w^{A}$ corresponds to the logarithm of the gross hourly wage of worker $\mathrm{i}$ in country A, and $X_{k}^{A}$ and $\varepsilon^{A}$ are the k-th explanatory variable and a random error term, respectively.

Taking in both sides of equation (1) the covariance with respect to the log-wages, the variance of log-wages in country A can be expressed by means of the following identity:

$$
\sigma_{w^{t}}^{2}=\sigma_{\sum_{k=1}^{K-1} \beta_{k}^{A} X_{k}^{A}, w^{A}}+\sigma_{\varepsilon^{A}, w^{A}}=\sum_{k=1}^{K-1} \sigma_{\beta_{k}^{A} X_{k}^{A}, w^{A}}+\sigma_{\varepsilon^{A}, w^{A}}
$$

where $\sigma_{w^{A}}^{2}, \sigma_{\beta_{k}^{A} X_{k}^{A}, w^{A}}$ and $\sigma_{\varepsilon^{A}, w^{A}}$ are, respectively, the variance of log-wages, the covariance of $\beta_{k}^{A} X_{k}^{A}$ and $w^{A}$ and the covariance of $\varepsilon^{A}$ and $w^{A}$. Moreover, $\sigma_{\varepsilon^{A}, w^{A}}=\sigma_{\varepsilon^{A}}^{2}$, as long as, by the properties of the OLS estimator, $\sigma_{\varepsilon^{4}, x_{k}^{4}}=0$, where $\mathrm{k}=1, \ldots, \mathrm{K}-1$.

Dividing both sides of the equation (2) by $\sigma_{w^{A}}^{2}$, equation (3) follows:

$$
1=\left(\sum_{k=1}^{K-1} \sigma_{\beta_{k}^{A} X_{k}^{A}, w^{A}}+\sigma_{\varepsilon^{A}, w^{A}}\right) / \sigma_{w^{A}}^{2}=\sum_{k=1}^{K} S_{k, A}
$$

where the 'relative factor inequality weight' $S_{k, A}$ measures the relative weight in the variance of logwages in country A of the k-th explanatory variable. These factors are made up of K-1 factors corresponding to the explanatory variables and factor $\mathrm{K}$, corresponding to the residuals, that is dealt with like a factor with coefficient equal to $1\left(\beta_{K}^{A}=1\right)$. This last factor is defined as $\sigma_{\varepsilon^{A}, w^{4}} / \sigma_{w^{4}}^{2}$, whereas in the case of the remaining K-1 factors corresponding to the explanatory variables $S_{k, t}$ the corresponding factor is defined $\mathrm{as}^{7}$ :

$$
S_{k, A}=\sigma_{\beta_{k}^{A} X_{k}^{A}, w^{A}} / \sigma_{w^{A}}^{2}=\left(\beta_{k}^{A} \sigma_{X_{k}^{A}} \varrho_{X_{k}^{A}, w^{A}}\right) / \sigma_{w^{A}}
$$

where $\sigma_{X_{k}^{A}}$ is the standard deviation of $X_{k}^{A}$ and $\varrho_{X_{k}^{A}, w^{A}}$ is the coefficient of correlation between $X_{k}^{A}$ and $w^{A}$ (that is to say, $\varrho_{X_{k}^{A}, w^{A}}=\sigma_{X_{k}^{A}, w^{A}} / \sigma_{X_{k}^{A}} \sigma_{w^{A}}$ ). Thus, the influence of each variable in wage inequality depends on its coefficient and on its dispersion.

As long as $\sum_{k=1}^{K} S_{k, A}=1$, the variance of log-wages in country A can be exactly broken down in the sum of the proportion explained by each explanatory variable in equation (1). Moreover, if the residual factor is excluded, the sum of the remaining factors is equal to the unadjusted coefficient of determination of the regression, so that $\sum_{k=1}^{K-1} S_{k, A}=R^{2}\left(w^{A}\right)$.

\footnotetext{
${ }^{7}$ Notice that if $\beta_{k}^{A}$ and $\varrho_{X_{k}^{A}, w^{A}}$ have opposite signs, the sign of $S_{k, A}$ can be negative.
} 
A shortcoming of this method is that the decomposition of the wage inequality that is provides is a priori valid solely for the variance of the log as inequality measure. Although this is a natural measure of inequality dispersion in the context of a regression analysis and its use to quantify inequality is relatively standard in economic literature, it displays certain non-desirable characteristics, like the fact that it violates the Pigou-Dalton principle of transference (Sen, 1973 and Foster and Ok, 1999). Yet, as Shorrocks (1982) demonstrated, if a variable can be expressed as the sum of different factors, under six generic axioms the relative weight in the inequality of the variable of factor $S_{k, A}$ as expressed in equation (4) is invariant for all the measures of inequality that fulfil certain properties (in particular, being continuous and symmetrical and taking a zero value if all the observations correspond to the average of the sample). Following Fields (2003), the theorem of Shorrocks (1982) on the decomposition of inequality on additive components is of direct application, by homeomorphism, to the context of the regression analysis based on the equation (1), whenever the explanatory variables enter the equation linearly. ${ }^{8}$ For that reason, the results expressed by equations (3) and (4) are applicable to other measures of inequality different from the variance of the logarithms that satisfy the previous conditions. This circumstance implies that the proportion of wage inequality explained by each factor $S_{k}$, (and, by extension, the overall results of the decomposition), is invariant, under certain conditions, for an ample set of inequality measures, including, as a matter of fact, the Gini index and the indices of the family of generalized entropy.

\subsection{Decomposing international differences in wage inequality}

\subsubsection{The Fields (2003) methodology}

In the empirical analysis, an extension of the Fields (2003) technique is initially applied to break down inter-country differences in the level of the wage inequality on the contribution of separate factors. In this case, the contribution of the $\mathrm{k}$-th variable to differences in inequality between countries $\mathrm{A}$ and $\mathrm{B}$ as measured by the difference in the variance of log-wages can be expressed as:

$$
\Pi_{k}(I)=\left(S_{k, A} I_{A}-S_{k, B} I_{B}\right)
$$

where $I_{c}$ is the variance of log-wages in country c $(\mathrm{c}=\mathrm{A}, \mathrm{B})$ and $S_{k, x}$ is the relative weight of factor $\mathrm{k}$ in the level of wage inequality of country c. ${ }^{9}$ Factor $\Pi_{k}(I)$ picks up the part of inter-country differences in wage inequality that is explained by the $\mathrm{k}$-th variable, so that $I_{A}-I_{B}=\sum_{k=1}^{K}\left(S_{k, A} I_{A}-S_{k, B} I_{B}\right)$.

\footnotetext{
${ }^{8}$ As a result, the use of interactions between variables is not possible when applying this technique.

${ }^{9}$ The Fields (2003) decomposition can actually be applied to any inequality measure. Notice that the contribution of each variable to international differences in wage inequality depends on the choice of inequality measure.
} 
Whenever that $I_{A}>I_{B}$, a positive value (negative) of $\Pi_{k}(I)$ indicates that factor $\mathrm{k}$ contributes to a greater (smaller) inequality in country A relative to country B.

Although the Fields (2003) technique allows obtaining information on the contribution of each factor to inter-country differences in the level of wage inequality and, thus, provides a rich picture of its origin, it does not permit to distinguish between coefficients (price) and characteristics (quantity) effects for each variable. For that reason, the Yun (2003) decomposition technique is used, in addition, in the empirical analysis. Its main advantage relative to the Fields (2003) decomposition is, precisely, that it allows to examine the influence on wage inequality of international differences in both endowments of observed characteristics and their returns.

\subsubsection{The Yun (2006) methodology}

The Yun (2006) methodology is a synthesis of the methodologies of Fields (2003) and Juhn et al. (1993). This later technique involves building hypothetical wages for each individual, then using the hypothetical wage distribution thus obtained to calculate counterfactual measures of wage inequality, to finally decompose differences in wage inequality between two countries according to their differences in observed characteristics, the returns to the characteristics and unobserved factors (for more details, see Juhn et al., 1993 and Blau and Kahn, 1996, 2005). Yet, an important drawback of this technique consists of that the decomposition of international differences in inequality in the contribution of cross-country differences in coefficients, characteristics and unobserved factors is solely valid at an aggregate level. In contrast, the Yun (2006) technique allows to break down international differences in wage inequality into the detailed contribution of cross-country differences in coefficients and characteristics of each variable (plus the effect of differences in the aggregate effect of unobserved factors). Thus, in short, this unified methodology allows to avoid the main shortcomings of both the Fields (2003) technique (namely, that the gross contribution of each separate factor to international differences in inequality can not be released in separate effects associated to prices and endowments) and the Juhn et al. (1993) technique (that is, that although international differences in the inequality can be broken down in the contribution of coefficients, measured characteristics and residuals, the decomposition is solely valid at an aggregate level for all the explanatory variables, so that it does not permit to disaggregate the different components into the detailed effect of each factor). As a consequence, it offers a more complete vision of the origin of international differences in wage inequality. (On the other hand, note that a limitation of this method is that it is exclusively applicable to the variance of log-wages.)

To implement this technique, in order to decompose differences in wage inequality between countries $\mathrm{A}$ and $\mathrm{B}$, the following wage function is estimated separately for the two countries: 


$$
\begin{aligned}
& w_{i}^{A}=X_{i}^{A} \beta^{A}+\varepsilon_{i}^{A} \\
& w_{i}^{B}=X_{i}^{B} \beta^{B}+\varepsilon_{i}^{B}
\end{aligned}
$$

where superscripts $A$ and $B$ correspond to countries $\mathrm{A}$ and $\mathrm{B}$, respectively; $w_{i}^{c}$ corresponds to the logarithm of the gross hourly wage of worker $\mathrm{i}$ in country c $(\mathrm{c}=\mathrm{A}, \mathrm{B}) ; X_{i}^{c}$ is a vector of explanatory variables (including a constant term); $\beta^{c}$ is the parameter vector estimated for country c; and $\varepsilon_{i}^{c}$ is an individual random error term.

After the separate estimation of equations (6) and (7), the next step of the technique consists of the estimation of the following auxiliary regression, in which wage returns estimated for country A with equation (6) are substituted by those estimated for country B with equation (7):

$$
w^{*}=X^{A} \beta^{B}+\varepsilon^{A}
$$

Then, the relative weight factors in global wage inequality of each variable are calculated for both actual wages and counterfactual wages constructed with the auxiliary regression given by equation (8). From such factors, the difference between countries $\mathrm{A}$ and $\mathrm{B}$ in the variance of the logwages is decomposed of the following form: ${ }^{10}$

$$
\sigma_{A}^{2}-\sigma_{B}^{2}=\left(\sigma_{A}^{2}-\sigma_{*}^{2}\right)-\left(\sigma_{*}^{2}-\sigma_{B}^{2}\right)=\sum_{k=1}^{K}\left(S_{k, A} \sigma_{A}^{2}-S_{k, *} \sigma_{*}^{2}\right)+\sum_{k=1}^{K}\left(S_{k, *} \sigma_{*}^{2}-S_{k, B} \sigma_{B}^{2}\right)
$$

where $\sigma_{*}^{2}$ is the variance of counterfactual log-wages, the first K-1 factors correspond to the exogenous variables and factor $\mathrm{K}$ correspond to the residual, with its coefficient of value one (alternately put, $\beta_{K}^{A}=\beta_{K}^{B}=1$ ).

In order to easily identify the characteristics, coefficients and wage residuals effects, equation (9) can be expressed alternatively in the following manner:

$$
\sigma_{A}^{2}-\sigma_{B}^{2}=\left(\sigma_{A}^{2}-\sigma_{*}^{2}\right)-\left(\sigma_{*}^{2}-\sigma_{B}^{2}\right)=\sum_{k=1}^{K}\left(S_{k, A} \sigma_{A}^{2}-S_{k, *} \sigma_{*}^{2}\right)+\sum_{k=1}^{K}\left(S_{k, *} \sigma_{*}^{2}-S_{k, B} \sigma_{B}^{2}\right)+\left(\sigma_{\varepsilon^{A}}^{2}-\sigma_{\varepsilon^{B}}^{2}\right)
$$

where the first and second terms of the right-hand side of the equation correspond to the sums of the effects of inter-country differences in returns and characteristics, respectively, and the third term captures the residual effect.

\footnotetext{
${ }^{10}$ In order to carry out the full Juhn et al. (1993) decomposition an alternative auxiliary regression should be calculated replacing both wage returns and characteristics of country $A$ in equation (6) by those of country B (that is, $\left.w^{* *}=X^{B} \beta^{B}+\varepsilon^{A}\right)$. Thus, if wage inequality is measured by $I_{o}$ and $I_{*}$ and $I_{* *}$ are the values of the same measure of wage inequality in the case of the previous counterfactual distributions, inter-country differences in wage inequalities between countries $\mathrm{A}$ and $\mathrm{B}$ could be expressed in terms of differences in returns, characteristics and unobserved factors as $\left(I_{A}-I_{B}\right)=\left(I_{A}-I_{*}\right)+\left(I_{*}-I_{* *}\right)+\left(I_{* *}-I_{B}\right)$. Yet, in order to develop the Yun (2006) technique it is not necessary to calculate this alternative auxiliary regression, as long as the effect of residuals is already measured by $\left(S_{K, A} \sigma_{A}^{2}-S_{K, B} \sigma_{B}^{2}\right)$, which is equal to $\left(S_{K, *} \sigma_{*}^{2}-S_{K, B} \sigma_{B}^{2}\right)$, given that $\left(S_{K, A} \sigma_{A}^{2}-S_{K, *} \sigma_{*}^{2}\right)$ equals zero.
} 


\section{Results}

\subsection{Decomposing within-country levels of wage inequality}

Table 2 reports the results of the within-country decompositions of wage inequality, obtained by applying the Fields (2003) decomposition to alternative specifications of equation (1). In order to ensure cross-country comparability of the empirical evidence, these specifications are similar for all the countries in the sample. The results in columns labelled Model 1 correspond to the use of a parsimonious specification where explanatory variables are individual characteristics. These individual controls comprise a gender indicator and a set of traditional human capital variables that proxy productivity endowments: the highest level of education reached by the individual (six levels are considered); age and its squared term (as a proxy for experience) and the time spent with the current employer and its squared term. Specification for Model 2 adds detailed controls for job characteristics (concretely, dummies for 27 major occupational groups and indicators for a permanent contract and a full-time job) and workplace characteristics. ${ }^{11}$ These are indicators for industry (55 dummies; 47 for Norway, Latvia, Italy and Portugal); the type of financial control (a dummy for fully publicly owned firms); size (five dummies) and a set of characteristics of the workplace labour force (specifically, the ratio to all employees in the wokplace of women, low- and high-educated workers -as defined as those workers with lower than upper-secondary and with tertiary education, respectively- and the average age and tenure). ${ }^{12}$

The contribution of each variable to wage inequality in Table 2 is measured by its relative factor inequality weight $S_{j}$. In order to interpret these results, let us notice that the joint effect of a set of related variables (as, for instance, age and its squared term or industry dummies) is computed by aggregating the relevant separate factors.

Results arising from Model 1 suggest prima facie that population heterogeneity accounts for a broad portion of wage inequality in every European economy. Therefore, individual characteristics explain from $18.5 \%$ of total inequality in Latvia to $55.3 \%$ in the Netherlands, with an unweighted average for all nine countries of 36.6\% (see final columns of Table 2). Yet, outcomes of Model 2 reveal that a significant part of the effect of individual factors arises from the uneven distribution across jobs and firms of workers with different characteristics. Thus, the explanatory power of

\footnotetext{
${ }^{11}$ Note that, in order to employ a specification of wage equation (1) similar for all countries, workplace characteristics are used as controls instead of workplace effects. The estimated earning functions for the fully specified Model 2 are reported in Table A.1 in the Appendix. The general econometric results are fairly standard, so they are not discussed.

${ }^{12}$ Many of these workplace characteristics are usual controls in empirical analyses on wage determination. Yet, let us notice, specifically, that the set of characteristics of the workplace labour force has been included providing the evidence that a higher presence of women in a firm depresses overall wages (Bayard et al., 2003 and Amuedo-Dorantes and De la Rica, 2006) and that the average human capital endowment of a firm's workforce affects the individual wages of all its workers, due plausibly to human capital externalities, such as productive complementarities and knowledge diffusion (Battu et al., 2003).
} 
individual characteristics on total wage inequality diminishes significantly in almost every case (the unweighted average effect of individual factors in Model 2 is $17.2 \%$, although in the Netherlands they still explain $38.1 \%$ of total inequality). The decrease is particularly noticeable as regards education, an element whose actual impact on total wage inequality lies in between $1.9 \%$ in Spain and 13.7 in the Netherlands (with an unweighted average of 6.5\%), which contrasts with usual considerations on its outstanding influence on wage inequality (see, for instance, Peracchi, 2006). Overall, this evidence reveals that although individual characteristics play a part in shaping wage inequality, in all European countries most of wage dispersion occurs among workers who are identical by measured skill and other observed individual characteristics. An additional point to note is that noteworthy international heterogeneity is observed with reference to both the total impact of individual characteristics and the specific effect of each individual factor. As a matter of fact, in the Netherlands individual characteristics explain $38.1 \%$ of wage inequality and the highest impact of a single individual factor corresponds to age (19.1\%), whereas in Latvia these factors explain $6 \%$ of total inequality and age has a negligible impact on inequality.

In turn, job and workplace characteristics explain in general an outstanding portion of wage inequality in every case: their joint influence goes from $24.3 \%$ of total inequality in the Netherlands to $52.8 \%$ in Portugal. Moreover, it is much more important than that of individual factors for almost all the countries in the sample so that, aside of the Netherlands, the explanatory power of these factors is several times that of individual factors. Consequently, job and workplace characteristics explain $21.1 \%$ and $18.7 \%$ of total within-country wage inequality on average, whereas, as noted before, the unweighted average effect of individual factors in Model 2 is $17.2 \%$.

As regards specific job characteristics, the impact of occupation is considerable, given that it explains between $9 \%$ of total inequality in Latvia and $27.4 \%$ in Lithuania (the unweighted average for the nine countries is $19.7 \%$ ), whereas the type of contract and the type of job exert just a minor influence on wage inequality. Concerning workplace characteristics, the main observed influence corresponds to industry (inter-industry wage differentials explain between $3.1 \%$ of total inequality in Lithuania and $15 \%$ in Slovakia, with an unweighted average of $8.0 \%$ ); to the composition of the workforce (the joint effect of related variables is in the range between $4 \%$ of total inequality in Italy and Lithuania to $10.5 \%$ in the Czech Republic, with an unweighted average of $7.3 \%$ ) and, although only in some countries, to size (it explains around 4-5\% of wage inequality in Spain, Italy Portugal, Lithuania and Latvia, but has a negligible impact in the remaining countries).

An additional point of concern is that Model 2 picks up a very significant portion of total wage variability in all the countries. This portion is in the range between $39.2 \%$ in Latvia and $70 \%$ in Portugal, although the model tends to explain in general the bulk of wage inequality in European 
countries (the unweighted average is $57.0 \%$ ). ${ }^{13}$ When workplace effects are considered in the specification of wage equation (1) instead of workplace attributes, the portion of wage inequality explained increases in every country (the unweighted average is $72.2 \%$ : see last row of Table 2 ). ${ }^{14}$ Yet, whereas the increase is roughly moderate in Norway, Slovakia and the Netherlands, it is somewhat more important in the Czech Republic, Italy and Portugal, and substantial in Spain, Lithuania and Latvia (in these last two countries the portion of wage inequality explained actually increases from $49.3 \%$ to $70.2 \%$ and from $39.2 \%$ to $77.2 \%$, respectively). Overall, this finding suggests that although the set of workplace indicators employed in the empirical analysis allows to partially control for the influence of workplaces on wages, there are unobserved workplace characteristics that affect wages in a significant manner which are not possible to control for with information on workplaces available in ESES samples. ${ }^{15}$ This result is consistent with the fact that wage differences between firms for similar workers can actually arise from very different grounds as, inter alia, the presence of limited or asymmetric information, firm-specific human capital or compensation policies, compensating wage differentials, efficiency wages or rent-sharing (for more details, see Groshen, 1991). ${ }^{16}$

Overall, obtained evidence shows that total wage inequality is generally more strongly associated in every European country to workplace and job attributes, so that workforce characteristics play a less influential part. Yet, it also reveals the influence in wage inequality of individual, job and workplace characteristics displays a significant international heterogeneity in our set of European countries, which implies that there is ample room for cross-country differences in these factors playing a part in shaping international differences in inequality. An in-depth analysis of this issue is carried out in the next subsection of the study.

\footnotetext{
13 As stressed in the previous section, these values coincide with the unadjusted coefficients of determination of the regression of wage equations. These are very similar, indeed, to the adjusted coefficients of determination (see Table A.1 of the Appendix).

${ }^{14}$ For technical reasons regarding the remote access to the ESES microdata, it has not been possible to carry out the full Fields (2003) decomposition for the model with workplace effects. Yet, as long as the aggregate explanatory power of all individual factors in this decomposition coincides with the unadjusted coefficient of determination of the regression of the relevant wage equation, it has been possible to estimate it by regressing equation (1) with a set of workplace effects. Given the result of the Hausman's contrast, they have been estimated as fixed effects for all the countries.

${ }^{15}$ Let us notice that additional inclusion of country-specific indicators on the type of collective agreement covering the workplace for countries where that information is available increases just very slightly the explained part of wage inequality in these countries. These results are available from the author on request.

${ }^{16}$ Moreover, it must be considered that, given that it is not possible to identify these effects in ESES cross-section microdata, workplace specific effects also capture unobservable individual and individual-firm match effects and that not controlling for them can be misleading. Existing evidence for several countries suggests that unobserved individual effects tend in general to be weakly correlated with workplace specific effects (see Goux and Maurin, 1999, Abowd et al., 2001 and the review in Lane, 2008). On the other hand, the findings by Woodcock (2007) suggest that even though match effects make a negligible contribution to observed inter-industry or male-female earnings differentials, they are important for correcting bias in estimated person and firm effects. In particular, according to the evidence in this study, the dispersion of firm effects in the United States is slightly higher when match effects are controlled for.
} 


\subsection{Decomposing international differences in wage inequality}

The results of applying the Fields (2003) technique to break down the contribution of explanatory factors to international differences in wage inequality as measured by the variance of logwages can be found in Table 3 (summary results) and Table 4 (full results of pairwise country comparisons). ${ }^{17}$ These tables show, in turn, the results obtained with two specifications of wage equation (1) analogous to previous parsimonious Model 1 with individual controls and Model 2 comprising also workplace and job characteristics. Including these later indicators is desirable in order to control for the effect of differences across countries in job and workplace mix in measuring the impact of individual factors on differences in wage inequality. However, let us notice that, as Blau and Kahn (2005) argue, these factors may affect wages both directly, holding job and workplace constant, and indirectly, through their effect on representation in higher-paying workplaces and jobs. Thus, regressions including job and workplace variables could not be illustrative of the total effect of these variables. For that reason, we focus on models that, in turn, include and exclude these variables.

The first two columns of Table 3 comprise the average results of the decomposition of international differences in wage inequality for all the possible pairwise comparisons of the nine countries in the sample. ${ }^{18}$ The average international difference in wage inequality for the nine countries in the sample is of 0.144 points, which amounts to $50.3 \%$ of the average within-country level of wage inequality of 0.286 points and is, thus, substantial. Results from Model 1 reveal that differences in individual characteristics explain on average 0.031 points of the average international difference in wage inequality of 0.144 points, being particularly important the effect of education (0.024) and tenure (0.012). Yet, average results are very influenced by the particular findings of the pairwise comparisons that comprise either Latvia or Lithuania, two countries where the effect of individual characteristics on wages is particularly low and that of unobserved factors is specially high. Thus, if Latvia and Lithuania are excluded (see the results in last two columns of Table 3), the average portion of international differences in wage inequality explained by workforce heterogeneity becomes much more significant: cross-country differences in individual observed characteristics explain in this case the bulk (0.054 points) of international differences in wage inequality (0.093), whereas the unexplained part (0.039) is comparatively less important.

\footnotetext{
17 Table 4 contains results obtained grouping individual, job- and workplace-related factors. More detailed results comprising the effect of all individual explanatory factors for each pairwise country comparison are available from the author on request.

${ }^{18}$ For each pair of countries the comparison where the difference in wage inequality is positive has been used in the analysis. The total amount of comparisons is, thus, 36.
} 
Results from fully specified Model 2 reveal, nevertheless, that when job and workplace characteristics are also taken into consideration the influence of individual factors diminishes considerably, so that job and workplace characteristics are comparatively more influential in shaping international differences in wage inequality. Hence, heterogeneity in individual, job and workplace attributes explain on average $0.004,0.023$ and 0.032 points of a total average difference of 0.141 (0.019, 0.021 and 0.026 of a total difference of 0.093 if Latvia and Lithuania are excluded of the analysis), whereas unobserved factors explain 0.084 points (0.027 without Latvia and Lithuania). Therefore, a sizeable portion of international differences in inequality is generally explained, though very specially when pairwise comparisons of Latvia and Lithuania are not considered. Also of concern is the effect of certain specific individual factors in shaping international differences in wage inequality: it should be stressed the particularly low explanatory power of cross-country differences in inequality of education (0.003), and that the more influential job and firm attributes are occupation (0.021), industry (0.005), size (0.009) and workforce composition (0.016).

Prior evidence suggests, overall, that in most cases workplace characteristics are a more important origin of international differences in inequality than individual and job-related factors. This feature is more clean-cut from the results of certain specific pairwise comparisons, yet. First panel of Table 4 reports all the pairwise comparisons of Latvia, the country in the sample with the highest wage inequality, with the remaining countries. In every case, workplace-related factors are the origin of a sizeable higher wage inequality in Latvia relative to any other European country. Hence, on average they generate a higher inequality of 0.074 points in Latvia (with a maximum of 0.101 points relative to Norway, the country in the sample with the lowest wage inequality), whereas job-related factors have an average negligible impact on inequality (-0.004) and workforce heterogeneity (-0.013) ceteris paribus would actually generate a lower inequality in Latvia relative to other European countries. Although a somewhat different evidence is found for Lithuania (job-related factors are the main identified origin of the comparatively high wage inequality in this country and workplace characteristics play an almost negligible part), quite similar results are observed when comparing Portugal, another European country with a remarkably dispersed wage structure, with those countries with a lower inequality (i.e. all the remaining countries except for Latvia and Lithuania). In this case, workplace-related factors are the origin of an average higher inequality in Portugal of 0.068 points, an effect which is roughly similar to the joint effect of workforce heterogeneity (0.020) and job-related factors (0.050). On the other hand, the evidence from the pairwise comparisons of the countries with the lowest inequality in the sample is highly parallel: when comparing with countries with a higher wage inequality, workplace-related factors are on average the origin of a sizeable lower inequality in Norway, Italy and the Czech Republic (-0.040, -0.030 and -0.033 points, respectively), 
whereas the effect of workforce heterogeneity $(-0.017,-0.019$ and -0.013$)$ and job-related factors ($0.025,-0.029$ and -0.020$)$ is somewhat less important when explaining their lower wage inequality relative to other European countries.

The results of applying the unified technique developed by Yun (2006) to comprehensively evaluate the price and quantity effects of individual explanatory factors to international differences in wage inequality can be found in Table 5 (summary results) and Table 6 (full results of pairwise comparisons). It must be stressed that, for a question of space, the results from the decomposition of international differences in wage inequality for all the possible pairwise comparisons of the nine countries in the sample correspond just to those from Model 2. ${ }^{19}$

Evidence in Table 5 shows that the aggregate effect of cross-country differences in the endowment of observed characteristics explains on average 0.024 points of the average international difference in inequality (0.144), so that differences in returns explain a higher portion ( 0.036 points) of the total effect of observed characteristics in shaping international differences in wage inequality (0.060). Interestingly, the most important influence corresponds to differences in the rewards to workplace characteristics (with a joint effect of 0.033), so that they have a higher impact on international differences in wage inequality than differences in endowments of workplace characteristics, whose influence is almost negligible (-0.001). This result suggests that international differences in inter-firm wage differentials (which, as noted previously, are strongly correlated with global wage inequality across countries) are mostly driven by differences in returns, instead of by differences in characteristics of workplaces.

These findings are, again, particularly clean-cut from the results for the countries with the comparatively highest and lowest wage inequality in the sample (Table 6). Thus, differences in endowments of characteristics would be in general the origin of a slightly higher inequality in Latvia relative to the other countries (the average effect is of 0.002 ), which actually contrasts with the significantly higher inequality displayed by this country $(0.273)$, whose main identified origin is the particularly way observed characteristics are rewarded there (0.054), very specially as regards workplace characteristics (0.086). In a similar vein, other things remaining equal, differences in endowments of characteristics would cause a comparatively higher inequality in Norway (0.034), so that the relatively lower inequality of this country (-0.169) is basically explained by differences in rewards to characteristics (-0.116), playing differences in workplace characteristics also an influential role in this case (-0.049).

\footnotetext{
19 Again, for each pair of countries the comparison where the difference in wage inequality is positive has been considered. The total amount of comparisons is 36. Let us notice that the results from the pairwise comparisons with the Yun (2006) decomposition may be sensitive to the particular order of the countries.
} 


\section{Conclusions}

This study has examined the origin of international differences in wage inequality in Europe. Wage inequality exhibits a very important heterogeneity across European countries and, for that reason, the examination of the origin of international differences in wage inequality in a set of nine representative European economies proves particularly informative. The research has been conducted on the basis of harmonized microdata drawn from a unique international matched employer-employee dataset, the European Structure of Earnings Survey. This survey is conducted in a significant number of European countries according to a common methodology so that the availability of this excellent source of strictly comparable data allows to obtain a full accounting of the effect of workforce, job- and firm-related factors on wage inequality and to explain a sizeable portion of international differences in wage inequality. This is a main advantage relative to previous studies on the origin of international differences in wage inequality, essentially based on microdata with rather limited information on significant wage-determining characteristics of workplaces and jobs, whose findings suggest that residual inequality with an unknown origin explain the bulk of cross-country differences in earnings inequality. By allowing to identify in the empirical analysis the part played in shaping wage inequality by a comprehensive set of factors, the use of international matched employer-employee data permits, thus, to shed additional light on the origin of international differences in wage inequality.

A major finding of the study is that global wage inequality is strongly correlated across European countries with the magnitude of inter-firm wage differentials, which suggests that workplaces play a substantial role in shaping wage inequality. Consistent with this, obtained evidence shows that workplace and job attributes are in general outstanding factors in the explanation of within-country wage inequality in all European countries and, conversely, that population heterogeneity plays a somewhat less significant part. This result suggests that most of wage dispersion inside European economies occurs among workers who are identical by measured skill and other individual characteristics and that a significant part of the effect of individual factors on wage inequality arises from the uneven distribution across workplaces and jobs of workers with different characteristics. From a policy perspective, these overall findings imply that public policy targeted at affecting firm heterogeneity can influence earnings distribution as much as interventions in fields such as education and training.

Obtained evidence reveals, on the whole, that European countries exhibit considerably different wage structures: they differ significantly not only in the extent of wage inequality, but also in the relative influence of factors shaping wage inequality. Consequently, results obtained in the empirical analysis 
show that the relative impacts of workplace, individual and job characteristics on wage inequality display a significant international heterogeneity and, accordingly, that these factors play a significant part in shaping international differences in inequality. Results from overall pairwise country comparisons suggest, in particular, that job and, very specially, workplace characteristics are more influential than individual characteristics in shaping international differences in wage inequality.

Finally, a remarkable result of the study is that differences in returns to characteristics explain more the influence of observed characteristics in shaping international differences in wage inequality than cross-country differences in endowments, which are less influential. This finding suggests that the explanation for cross-country differences in wage inequality lies to a lesser extent in the distribution of skills or job and workplace mix and more in the mechanism by which different pay systems produce dispersion among otherwise observationally similar workers, jobs and workplaces. Obtained evidence shows, moreover, that differences in the rewards to workplace characteristics play a particularly significant part in the explanation of international differences in wage inequality. This finding suggest, on the one hand, that international differences in inter-firm wage differentials, a major origin of international differences in global wage inequality, are not mostly driven by heterogeneity in firm populations but by differences in returns to firm characteristics. On the other hand, although it is beyond the scope of this research to assess to what extent the explanation of international differences in wage inequality rest on labour institutions such as collective bargaining, it is somewhat consistent, in the same vein that overall obtained evidence, with the hypothesis that there is more margin to inter-firm wage differentials in countries with decentralized wage-setting systems. 


\section{References}

Aagard, A.; Eriksson, T.; Westergaard-Nielsen, N. (2007): "Wage and Labour Mobility in Denmark, 1980 2000”, en E. Lazear and K. Shaw (eds.), Wage Structure, Raises and Mobility: International Comparisons of the Structure of Wages Within and Across Firms, ed. University of Chicago Press (forthcoming).

Abowd, J.M.; Kramarz, F. (1999): “The Analysis of Labour Markets Using Matched Employer-Employee Data", in O. Ashenfelter and D. Card (ed.) Handbook of Labour Economics, ed. North-Holland.

Abowd, J.M.; Kramarz, F.; Margolis, D.N.; Troske, K. (2001): “The Relative Importance of Employer and Employee Effects on Compensation: A Comparison of France and the United States", Journal of the Japanese and International Economics, No 15, pp. 419-436.

Amuedo-Dorantes, C.; De la Rica, S. (2006): "The Role of Segregation and Pay Structure on the Gender Wage Gap: Evidence from Matched Employer-Employee Data for Spain”, Contributions to Economic Analysis \& Policy, 5(1), pp. 1-32.

Battu, H.; Belfield, C.R.; Sloane, P.J. (2003): "Human Capital Spill-Overs Within the Workplace", Oxford Bulletin of Economics and Statistics, 65, pp. 575-594.

Bayard, K.; Hellerstein, J.; Neumark, D.; Troske, K. (2003): "New evidence on sex segregation and sex differences in wages from matched employee-employer data", Journal of Labor Economics, vol. 21, nº 4, pp. 887-922.

Blau, F.D.; Kahn, L.M. (1996): “International Differences in Male Wage Inequality: Institutions versus Market Forces”, Journal of Political Economy, 101(4), pp. 791-837.

Blau, F.D.; Kahn, L.M. (1999): "Institutions and Laws in the Labour Market", in O. Ashenfelter and D. Card (ed.) Handbook of Labour Economics, ed. North-Holland.

Blau, F.D.; Kahn, L.M. (2005): "Do cognitive test scores explain higher US wage inequality?", The Review of Economics and Statistics, 87(1), pp. 184-193.

Cardoso, A.R. (1999): “Firms' wage policies and the rise in labour market inequality: The case of Portugal", Industrial and Labour Relations Review, Vol. 53(1), pp. 87-102.

Davis, S.J.; Haltiwanger, J. (1991): "Wage Dispersion between and within US Manufacturing Plants, 1963-86", Brooking Papers on Economic Activity, Special Issue, pp. 115-80.

Devroye, D.; Freeman, R. (2002): "Does Inequality in Skills Explain Inequality of Earnings Across Advanced Countries?”, CEP Discussion Papers 0552.

Dunne, T.; Foster, L.; Haltiwanger, J.; Troske, K. (2004): "Wage and Productivity Dispersion in United States Manufacturing: The Role of Computer Investment”, Journal of Labour Economics, 22(2), pp. 397-429.

European Commission (2004): Industrial Relations in Europe 2004.

European Industrial Relations Observatory (2002): "Industrial relations in the EU Member States and candidate countries", available in http://www.eiro.eurofound.eu.int.

European Industrial Relations Observatory (2005): "Minimum wages in Europe", available in http://www.eiro.eurofound.eu.int.

Eurostat (2003): Employment in Europe. 2003.

Eurostat (2005): Employment in Europe. 2005.

Fields, G.S. (2003): “Accounting for Income Inequality and its Change: A New Method with Application to U.S. Earnings Inequality" in S.W. Polacheck (ed.), Research in Labour Economics, Vol. 22: Worker Well-Being and Public Policy, Oxford, pp. 1-38.

Foster, J.; Ok, E. (1999): “Lorenz dominance and the variance of logarithms”, Econometrica, 67(4), pp. 901-8.

Freeman, R. (2007): "Labour market institutions around the world", NBER Working Paper 13242.

Goux, D.; Maurin, E. (1999): "Persistence of Inter-industry Wage Differentials: A Re-examination Using Matched Worker-Firm panel Data”, Journal of Labor Economics, vol. 17, n 3, pp. 492-533.

Groshen, E.L. (1991): “Five Reasons Why Wages Vary Among Employers”, Industrial Relations, vol. 30, no 4, pp. 350-381.

Haltiwanger, J.C., Lane, J., Spletzer, J.R., Theeuwes, J.J. and K. Troske (1999): The Creation and Analysis of EmployerEmployee Matched Data, ed. North-Holland, Amsterdam.

Hamermesh, D. (2007): "Fun with matched firm-employee data: Progress and road maps", Labour Economics (doi:10.1016/j.labeco.2007.05.004).

Juhn, C., Murphy, K.; Pierce, B. (1993): “Wage inequality and the rise in returns to skill”, Journal of Political Economy, 101(31), pp. 410-442. 
Katz, L.F.; Autor, D.H. (1999): "Change in the Wage Structure and Earnings Inequality", in O. Ashenfelter and D. Card (ed.) Handbook of Labour Economics, ed. North-Holland.

Lallemand, T.; Plasman, R.; Rycx, F. (2007): "The Establishment-Size Wage Premium: Evidence from European Countries", Empirica, vol. 34, no. 5, pp. 427-451.

Lane, J. (2008): "Inequality and the Labour Market: Employers," in B. Nolan, W. Salverda and T. Smeeding (eds.) Handbook of Income Inequality, ed. Oxford University Press (forthcoming).

Lazear, E.; Shaw, K. (2007): "Wage Structure, Raises and Mobility: International Comparisons of the Structure of Wages Within and Across Firms", NBER Working Paper 13654.

Leuven, E.; Oosterbeek, H. (2004): "Explaining international differences in male wage inequality by differences in demand and supply of skill", Economic Journal, 144, pp. 478-498.

Nickell, S. and Layard, R. (1999): "Labour market institutions and economic performance", O. Ashenfelter and D. Card (eds.) Handbook of Labour Economics, ed. North-Holland.

Nordström-Skans, O.; Edin, P.; Homlund, B. (2007): "Wage Dispersion Between and Within Plants: Sweden 1985-2000", en E. Lazear and K. Shaw (eds.), Wage Structure, Raises and Mobility: International Comparisons of the Structure of Wages Within and Across Firms, ed. University of Chicago Press (forthcoming).

OECD (2004): Employment Outlook 2004.

OECD (2007): Employment Outlook 2007.

Peracchi, F. (2006): "Educational Wage Premia and the Distribution of Earnings: An International Perspective", in E. Hanushek and F. Welch (eds.) Handbook of the Economics of Education, ed. NorthHolland.

Plasman R., Rusinek M. and Rycx F. (2007): "Wages and the Bargaining Regime under Multi-level Bargaining: Belgium, Denmark and Spain”, European Journal of Industrial Relations, vol. 13, pp. 161-180.

Rubery, J.; Grimshaw, D. and Figuereido, H. (2002): “The Gender Pay Gap and Gender Mainstreaming Pay Policy in EU Member States", Report for the Equal Opportunities Commission of the European Union.

Rutkowski, J. J. (2001): "Earnings inequality in Transition Economies of Central Europe, Trends and Patterns During the 1990s", Social Protection Discussion Paper Series n¹17, World Bank.

Sen, A. (1973): On Economic Inequality, ed. Oxford University Press.

Shorrocks, A.F. (1982): "Inequality Decomposition by Factor Components," Econometrica, 50(1), pp. 193-211.

Simón, H. (2005): "Employer Wage Differentials from an International Perspective", Economics Letters, 88(2), pp. 284-288.

Yun, M.S. (2006): "Earnings Inequality in the USA, 1961-1999: Comparing Inequality Using Earnings Equations", Review of Income and Wealth, 52(1), pp. 127-144. 
Table 1

Wage dispersion and wage-setting institutions. ESES 2002.

\begin{tabular}{|c|c|c|c|c|c|c|c|c|c|}
\hline & Norway & Italy & $\begin{array}{c}\text { Czech } \\
\text { Republic }\end{array}$ & Netherlands & Slovakia & Spain & Portugal & Lithuania & Latvia \\
\hline \multicolumn{10}{|l|}{ Hourly wage dispersion measures } \\
\hline 90-10 log differential & 0.891 & 1.002 & 1.060 & 1.139 & 1.190 & 1.289 & 1.545 & 1.591 & 1.786 \\
\hline 50-10 log differential & 0.316 & 0.398 & 0.517 & 0.566 & 0.561 & 0.493 & 0.576 & 0.747 & 0.588 \\
\hline $90-50 \log$ differential & 0.575 & 0.604 & 0.544 & 0.573 & 0.629 & 0.795 & 0.969 & 0.844 & 1.198 \\
\hline Variance of logarithms & 0.136 & 0.175 & 0.196 & 0.254 & 0.252 & 0.274 & 0.376 & 0.385 & 0.529 \\
\hline Mean $\log$ deviation & 0.077 & 0.104 & 0.116 & 0.123 & 0.162 & 0.158 & 0.225 & 0.217 & 0.442 \\
\hline Gini Index & 0.217 & 0.252 & 0.263 & 0.262 & 0.308 & 0.315 & 0.376 & 0.367 & 0.456 \\
\hline \multicolumn{10}{|l|}{ Wage-setting institutions } \\
\hline Union affiliation rate $(\%)^{a}$ & 54 & 35 & 30 & 27 & 36 & 15 & 24 & 15 & 30 \\
\hline Collective bargaining coverage rate $(\%)^{\mathrm{b}}$ & 70 & 80 & 25 & 80 & 50 & 80 & 80 & 14 & 20 \\
\hline Collective bargaining coordinationc ${ }^{c}$ & 4.5 & 4 & 1 & 4 & 2 & 3 & 4 & 1.5 & 1.5 \\
\hline Collective bargaining centralization ${ }^{\mathrm{d}}$ & 4.5 & 2 & 1 & 3 & 2 & 3 & 4 & 1 & 1 \\
\hline Statutory minimum wage/Average gross wage & - & - & 0.36 & 0.45 & 0.41 & 0.33 & 0.38 & 0.43 & 0.35 \\
\hline Regulatory mechanism of low-wages ${ }^{f}$ & $\begin{array}{l}\text { Collective } \\
\text { bargaining }\end{array}$ & $\begin{array}{l}\text { Collective } \\
\text { bargaining }\end{array}$ & $\begin{array}{l}\text { Minimum } \\
\text { wage }\end{array}$ & $\begin{array}{l}\text { Minimum } \\
\text { wage }\end{array}$ & $\begin{array}{l}\text { Minimum } \\
\text { wage }\end{array}$ & $\begin{array}{l}\text { Minimum } \\
\text { wage }\end{array}$ & $\begin{array}{l}\text { Minimum } \\
\text { wage }\end{array}$ & $\begin{array}{l}\text { Minimum } \\
\text { wage }\end{array}$ & $\begin{array}{l}\text { Minimum } \\
\text { wage }\end{array}$ \\
\hline \multicolumn{10}{|l|}{ Workplace effects standard deviation } \\
\hline Unadjusted & 0.218 & 0.311 & 0.284 & 0.320 & 0.276 & 0.421 & 0.497 & 0.421 & 0.604 \\
\hline Adjusted by individual and job controls & 0.126 & 0.243 & 0.228 & 0.167 & 0.254 & 0.302 & 0.334 & 0.368 & 0.566 \\
\hline Adjusted by workplace effects & 0.298 & 0.279 & 0.340 & 0.389 & 0.419 & 0.312 & 0.359 & 0.460 & 0.406 \\
\hline Adjusted by workplace effects and individual and job controls & 0.213 & 0.207 & 0.233 & 0.278 & 0.324 & 0.236 & 0.263 & 0.339 & 0.347 \\
\hline
\end{tabular}

OECD (2004): 2001 for the Czech Republic and 2000 for the other countries. EIRO (2002) for Latvia and Lithuania.

b Eurostat (2005).

c OECD (2004). Collective bargaining coordination in 1995-2000. 1=low coordination; $5=$ high coordination. A value of 1.5 has been assigned to Latvia and Lithuania on the basis of the information of European Commission (2004).

d OECD (2004). Predominant level of collective bargaining in 1995-2000. 1=company and plant level predominant; $2=$ combination of industry and company/plant level, with an important share of employees covered by company bargains; $3=$ industry-level predominant; $4=$ predominantly industrial bargaining, but also recurrent central-level agreements; $5=$ central-level agreements of overriding importance. EIRO (2002) for Latvia and Lithuania.

¿EIRO (2005). 2002 (2004 for Spain). For Portugal, Statutory minimum wage/Median gross wage.

${ }^{\mathrm{f}}$ Eurostat (2003).

Notes: $90-10,50-10$ and $90-50 \log$ differentials are the wage differentials between the $90^{\text {th }}-10^{\text {th }}, 50^{\text {th }}-10^{\text {th }}$ and $90^{\text {th }}-10^{\text {th }}$ deciles of the $\log$ hourly wage distribution. The unadjusted and adjusted dispersion of workplace wage differentials are the standard deviation of a set of workplace fixed effects estimated with two extended specifications of wage equation (1). These include, in turn, no other additional control and a full set of individual and job controls (gender, education, age and its squared term, tenure in the firm and its squared term, type of contract, full-time/part-time job and occupation) 
Table 2

Fields (2003) decomposition of within-country levels of wage inequality. ESES 2002.

\begin{tabular}{|c|c|c|c|c|c|c|c|c|c|c|c|c|c|c|c|c|c|c|c|c|}
\hline & \multicolumn{2}{|c|}{ Norway } & \multicolumn{2}{|c|}{$\overline{I t a l y}$} & \multicolumn{2}{|c|}{ Czech Republic } & \multicolumn{2}{|c|}{ Netherlands } & \multicolumn{2}{|c|}{ Slovakia } & \multicolumn{2}{|c|}{ Spain } & \multicolumn{2}{|c|}{ Portugal } & \multicolumn{2}{|c|}{ Lithuania } & \multicolumn{2}{|c|}{ Latvia } & \multicolumn{2}{|c|}{ Average } \\
\hline & Mod. 1 & Mod. 2 & Mod. 1 & Mod. 2 & Mod. 1 & Mod. 2 & Mod. 1 & Mod. 2 & Mod. 1 & Mod. 2 & Mod. 1 & Mod. 2 & Mod. 1 & Mod. 2 & Mod. 1 & Mod. 2 & Mod. 1 & Mod. 2 & Mod. 1 & Mod. 2 \\
\hline Aggregate & 0.406 & 0.620 & 0.348 & 0.560 & 0.349 & 0.613 & 0.553 & 0.625 & 0.293 & 0.546 & 0.407 & 0.577 & 0.497 & 0.700 & 0.252 & 0.493 & 0.185 & 0.392 & 0.366 & 0.570 \\
\hline Individual characteristics & 0.406 & 0.213 & 0.348 & 0.164 & 0.349 & 0.187 & 0.553 & 0.381 & 0.293 & 0.143 & 0.407 & 0.158 & 0.497 & 0.172 & 0.252 & 0.070 & 0.185 & 0.060 & 0.366 & 0.172 \\
\hline Gender & 0.057 & 0.031 & 0.030 & 0.025 & 0.076 & 0.062 & 0.034 & 0.023 & 0.090 & 0.052 & 0.042 & 0.027 & 0.031 & 0.016 & 0.008 & 0.005 & 0.010 & 0.005 & 0.042 & 0.027 \\
\hline Education & 0.180 & 0.071 & 0.194 & 0.059 & 0.217 & 0.089 & 0.238 & 0.137 & 0.159 & 0.056 & 0.166 & 0.019 & 0.325 & 0.077 & 0.201 & 0.046 & 0.109 & 0.029 & 0.199 & 0.065 \\
\hline Tenure & 0.017 & 0.014 & 0.057 & 0.028 & 0.049 & 0.026 & 0.054 & 0.030 & 0.037 & 0.021 & 0.147 & 0.075 & 0.073 & 0.040 & 0.042 & 0.018 & 0.067 & 0.026 & 0.060 & 0.031 \\
\hline Age & 0.152 & 0.097 & 0.067 & 0.052 & 0.007 & 0.010 & 0.227 & 0.191 & 0.008 & 0.015 & 0.051 & 0.037 & 0.069 & 0.040 & 0.000 & 0.001 & -0.002 & 0.000 & 0.064 & 0.049 \\
\hline Job characteristics & - & 0.260 & - & 0.201 & - & 0.243 & - & 0.151 & - & 0.164 & - & 0.236 & - & 0.249 & - & 0.289 & - & 0.103 & - & 0.211 \\
\hline Type of contract & - & 0.003 & - & 0.002 & - & 0.013 & - & 0.025 & - & 0.001 & - & 0.016 & - & 0.009 & - & 0.001 & - & 0.000 & - & 0.008 \\
\hline Full-time/Part-time & - & 0.018 & - & -0.002 & - & 0.000 & - & 0.006 & - & 0.006 & - & -0.002 & - & 0.000 & - & 0.014 & - & 0.011 & - & 0.006 \\
\hline Occupation & - & 0.240 & - & 0.201 & - & 0.230 & - & 0.120 & - & 0.157 & - & 0.223 & - & 0.240 & - & 0.274 & - & 0.092 & - & 0.197 \\
\hline Firm characteristics & - & 0.148 & - & 0.195 & - & 0.183 & - & 0.092 & - & 0.238 & - & 0.182 & - & 0.279 & - & 0.134 & - & 0.229 & - & 0.187 \\
\hline Industry & - & 0.094 & - & 0.102 & - & 0.066 & - & 0.051 & - & 0.150 & - & 0.046 & - & 0.133 & - & 0.031 & - & 0.050 & - & 0.080 \\
\hline Type of financial control & - & -0.002 & - & 0.001 & - & 0.003 & - & -0.008 & - & 0.009 & - & 0.000 & - & 0.012 & - & 0.021 & - & 0.012 & - & 0.005 \\
\hline Size & - & 0.005 & - & 0.053 & - & 0.009 & - & -0.001 & - & 0.011 & - & 0.045 & - & 0.051 & - & 0.035 & - & 0.049 & - & 0.029 \\
\hline Share of females & - & 0.003 & - & 0.004 & - & 0.041 & - & 0.008 & - & 0.060 & - & 0.011 & - & 0.004 & - & 0.001 & - & 0.002 & - & 0.015 \\
\hline Average age & - & -0.003 & - & 0.006 & - & -0.008 & - & 0.005 & - & -0.004 & - & 0.018 & - & -0.009 & - & 0.007 & - & 0.025 & - & 0.004 \\
\hline Average tenure & - & 0.004 & - & 0.001 & - & 0.003 & - & 0.002 & - & 0.005 & - & 0.011 & - & 0.008 & - & -0.002 & - & 0.000 & - & 0.004 \\
\hline Share of high-educated & - & 0.040 & - & 0.012 & - & 0.062 & - & 0.008 & - & 0.007 & - & 0.027 & - & 0.034 & - & 0.042 & - & 0.094 & - & 0.036 \\
\hline Share of low-educated & - & 0.006 & - & 0.018 & - & 0.007 & - & 0.027 & - & 0.003 & - & 0.023 & - & 0.047 & - & -0.001 & - & -0.003 & - & 0.014 \\
\hline $\begin{array}{l}\text { Wage residuals } \\
\text { Pro memoria }\end{array}$ & 0.594 & 0.380 & 0.652 & 0.440 & 0.651 & 0.387 & 0.447 & 0.375 & 0.707 & 0.454 & 0.593 & 0.423 & 0.503 & 0.300 & 0.748 & 0.507 & 0.816 & 0.608 & 0.634 & 0.430 \\
\hline $\begin{array}{l}\text { Aggregate with workplace effects } \\
\text { and individual and job controls }\end{array}$ & - & 0.667 & - & 0.754 & - & 0.720 & - & 0.692 & - & 0.584 & - & 0.795 & - & 0.816 & - & 0.702 & - & 0.772 & - & 0.722 \\
\hline
\end{tabular}


Table 3

Fields (2003) decomposition of international differences in wage inequality. Summary results. ESES 2002.

\begin{tabular}{|c|c|c|c|c|}
\hline & \multicolumn{2}{|c|}{$\begin{array}{l}\text { Average of all } \\
\text { pairwise } \\
\text { comparisons }\end{array}$} & \multicolumn{2}{|c|}{$\begin{array}{c}\text { Average of all } \\
\text { pairwise } \\
\text { comparisons } \\
\text { (without Latvia and } \\
\text { Lithuania) }\end{array}$} \\
\hline & Model 1 & Model 2 & Model 1 & Model 2 \\
\hline Aggregate & 0.031 & 0.060 & 0.054 & 0.066 \\
\hline Individual characteristics & 0.031 & 0.004 & 0.054 & 0.019 \\
\hline Gender & -0.002 & -0.002 & 0.002 & 0.001 \\
\hline Education & 0.024 & 0.003 & 0.032 & 0.006 \\
\hline Tenure & 0.012 & 0.005 & 0.013 & 0.007 \\
\hline Age & -0.003 & -0.003 & 0.007 & 0.005 \\
\hline Job characteristics & - & 0.023 & - & 0.021 \\
\hline Type of contract & - & 0.000 & - & 0.002 \\
\hline Full-time/Part-time & - & 0.002 & - & -0.001 \\
\hline Occupation & - & 0.021 & - & 0.020 \\
\hline Workplace characteristics & - & 0.032 & - & 0.026 \\
\hline Industry & - & 0.005 & - & 0.010 \\
\hline Type of financial control & - & 0.003 & - & 0.001 \\
\hline Size & - & 0.009 & - & 0.006 \\
\hline Workforce composition & - & 0.016 & - & 0.010 \\
\hline Wage residuals & 0.113 & 0.084 & 0.039 & 0.027 \\
\hline Difference in inequality & \multicolumn{2}{|c|}{0.144} & \multicolumn{2}{|c|}{0.093} \\
\hline
\end{tabular}

Notes: Table contains factors $\Pi_{k}(I)$ as expressed in equation (5). The average values in the table have been calculated from all the pairwise comparisons of the nine countries in the sample. 
Table 4

Fields (2003) decomposition of international differences in wage inequality. Full results. ESES 2002.

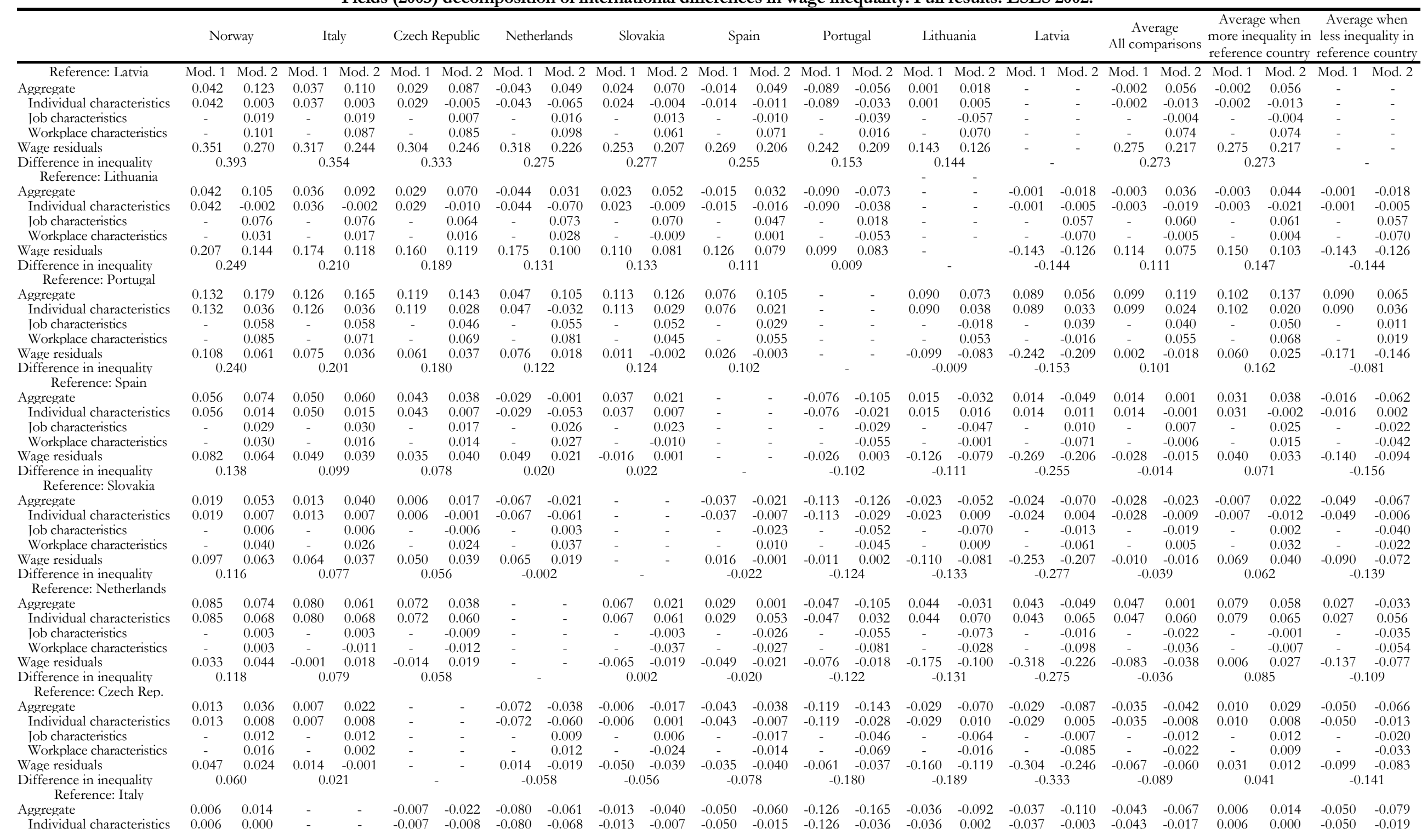


Job characteristics

Wage residuals

Difference in inequality

Reference: Norway

Aggregate
Individual characteristics

Individual characteristics
Job characteristics

Workplace characteristic

Wage residuals

\begin{tabular}{cc}
- & 0.000 \\
- & 0.014 \\
0.033 & 0.026 \\
\multicolumn{2}{c}{0.039} \\
$-\quad$ & -
\end{tabular}

$\begin{array}{lll}-0.012 & - & -0.003 \\ -0.002 & - & 0.011 \\ 0.001 & 0.001 & -0.018\end{array}$

$\begin{array}{lll}-0.003-0.006 & - & -0.00 \\ 0.011 & - & -0.026\end{array}$

$-0.006-0.030$

$-0.058--0.076$

$-0.076$

$-0.019$

$\begin{array}{lllll}-0.026 & - & 0.000 & - & -0.029 \\ -0.024 & - & 0.014 & -0.030\end{array}$

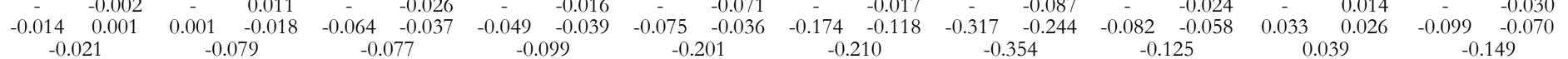

$\begin{array}{lllllllllllllllllllllll}-0.006 & -0.014 & -0.013 & -0.036 & -0.085 & -0.074 & -0.019 & -0.053 & -0.056 & -0.074 & -0.132 & -0.179 & -0.042 & -0.105 & -0.042 & -0.123 & -0.049 & -0.082 & - & - & -0.049 & -0.082 \\ -0.006 & 0.000 & -0.013 & -0.08 & -0.085 & -0.08 & -0.019 & -0.007 & -0.056 & -0.014 & -0.132 & -0.036 & -0.042 & 0.002 & -0.042 & -0.03 & -0.049 & -0.017 & - & - & -0.049 & -0.017\end{array}$

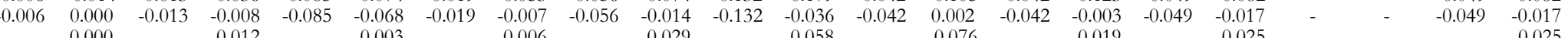

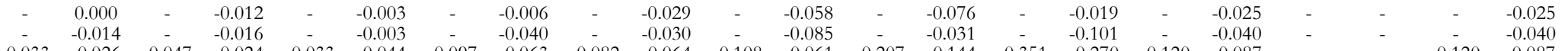

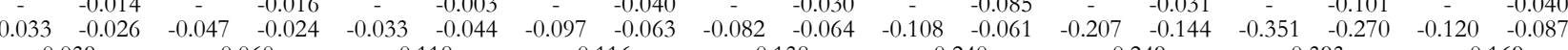

$-0.120 \quad-0.087$

Notes Table cont ins factors $\Pi_{(I)}$ as expressed in equation (5). 
Table 5

Yun (2006) decomposition of international differences in wage inequality. Summary results. ESES 2002.

\begin{tabular}{lcccc}
\hline & $\begin{array}{c}\text { Average of all } \\
\text { pairwise } \\
\text { comparisons }\end{array}$ & \multicolumn{2}{c}{$\begin{array}{c}\text { Average of all } \\
\text { pairwise } \\
\text { comparisons } \\
\text { (without Latvia and } \\
\text { Lithuania) }\end{array}$} \\
\hline Aggregate & $\begin{array}{c}\text { Charac. } \\
\text { Charac. }\end{array}$ & Returns \\
Individual characteristics & 0.024 & 0.036 & 0.034 & 0.032 \\
Gender & -0.002 & 0.007 & 0.002 & 0.016 \\
Education & 0.000 & -0.002 & 0.001 & 0.000 \\
Tenure & 0.003 & 0.000 & 0.004 & 0.003 \\
Age & -0.002 & 0.007 & 0.000 & 0.007 \\
Job characteristics & -0.003 & 0.002 & -0.002 & 0.007 \\
Type of contract & 0.027 & -0.004 & 0.025 & -0.004 \\
Full-time/Part-time & 0.000 & 0.001 & 0.001 & 0.001 \\
Occupation & 0.000 & 0.001 & 0.000 & 0.000 \\
Workplace characteristics & 0.027 & -0.006 & 0.025 & -0.005 \\
Industry & -0.001 & 0.033 & 0.006 & 0.020 \\
Type of financial control & -0.002 & 0.007 & 0.000 & 0.009 \\
Size & -0.001 & 0.004 & 0.000 & 0.001 \\
Workforce composition & -0.002 & 0.011 & 0.000 & 0.006 \\
Wage residuals & 0.003 & 0.012 & 0.007 & 0.003 \\
Difference in inequality & 0.084 & & 0.027 \\
\hline Notes: The average values in the table & have been & calculated & from all the & pairwise
\end{tabular}
comparisons of the nine countries in the sample. 
Table 6

Yun (2006) decomposition of international differences in wage inequality. Full results. ESES 2002.

\begin{tabular}{|c|c|c|c|c|c|c|c|c|c|c|c|c|c|c|c|c|c|c|c|c|c|c|c|c|}
\hline & \multicolumn{2}{|c|}{ Norway } & \multicolumn{2}{|c|}{ Italy } & \multicolumn{2}{|c|}{ Czech Republic } & \multicolumn{2}{|c|}{ Netherlands } & \multicolumn{2}{|c|}{ Slovakia } & \multicolumn{2}{|c|}{ Spain } & \multicolumn{2}{|c|}{ Portugal } & \multicolumn{2}{|c|}{ Lithuania } & \multicolumn{2}{|c|}{ Latvia } & \multicolumn{2}{|c|}{$\begin{array}{c}\text { Average } \\
\text { All comparisons }\end{array}$} & \multicolumn{2}{|c|}{$\begin{array}{l}\text { Average when } \\
\text { more inequality in } \\
\text { reference country }\end{array}$} & $\begin{array}{r}\text { Average } \\
\text { less ineq } \\
\text { reference }\end{array}$ & $\begin{array}{l}\text { ge when } \\
\text { quality in } \\
\text { e country }\end{array}$ \\
\hline Reference: Latvia & laract. & Returns & haract. & . Returns & & Returns & tharact. & Returns & naract. & Returns & Charact. & returns & Charact. & Returns & Charact. 1 & Returns & aract. & tur & Charact. & Returns & tharact. & Returns & Charact. & Returns \\
\hline rgregate & -0.018 & 0.141 & 0.128 & -0.019 & 0.061 & 0.026 & -0.078 & 0.126 & 0.041 & 0.029 & $\begin{array}{l}-0.026 \\
-1\end{array}$ & 0.075 & -0.044 & -0.012 & -0.050 & 0.068 & 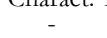 & the & 0.002 & 0.054 & 0.002 & 0.054 & & \\
\hline Individual characteristics & $\begin{array}{l}-0.010 \\
-0.009\end{array}$ & 0.012 & 0.007 & -0.004 & 0.008 & $\begin{array}{r}-0.020 \\
-0.013\end{array}$ & $\begin{array}{l}-0.048 \\
-0.048\end{array}$ & -0.017 & 0.022 & -0.026 & $\begin{array}{l}-0.013 \\
-0.013\end{array}$ & 0.002 & $\begin{array}{l}-0.0476 \\
-0.016\end{array}$ & $\begin{array}{l}-0.017 \\
-0.017\end{array}$ & $\begin{array}{l}-0.000 \\
-0.005\end{array}$ & 0.010 & & & -0.007 & $\begin{array}{r}-0.007 \\
-0.007\end{array}$ & -0.007 & -0.007 & & - \\
\hline chanctistict & -0.001 & 0.020 & 0.136 & -0.116 & 0.031 & -0.024 & -0.019 & 0.035 & 0.026 & -0.013 & 0.016 & -0.027 & 0.023 & -0.062 & -0.044 & -0.013 & & & 0.021 & & 0.021 & & & \\
\hline Workp & -0.008 & 0.109 & -0.014 & 0.101 & 0.023 & 0.062 & -0.011 & 0.108 & -0.007 & & -0.029 & 0.100 & -0.051 & & -0.001 & & & & -0.012 & & -0.012 & & & \\
\hline Wage resi & 0.270 & & $\begin{array}{l}-0.014 \\
0.244\end{array}$ & & 0.246 & & 0.226 & & 0.207 & & 0.206 & & 0.209 & & 0.126 & & - & & 0.217 & & 0.217 & & - & \\
\hline Difference & 0.393 & & 0.354 & & 0.333 & & 0.275 & & 0.277 & & 0.255 & & 0.153 & & 0.144 & & & & 0.273 & & 0.273 & & & \\
\hline Lithuania & Charact. & Returns & Charact. & Returns & Charact. & Returns & Charact. & Returns & Charact. & Returns & Charact. & Returns & Charact. & Returns & Charact. 1 & Returns & Charact. & Returns & Charact. & Returns & Charact. & Returns & Charact. & Returns \\
\hline Aggregate & -0.008 & 0.114 & 0.134 & -0.042 & 0.071 & -0.002 & -0.075 & 0.106 & 0.054 & -0.001 & 0.012 & 0.020 & -0.035 & -0.039 & & & 0.158 & -0.176 & 0.039 & & 0.022 & 0.022 & & -0.176 \\
\hline aracteristics & $\begin{array}{l}-0.000 \\
-0.008\end{array}$ & $\begin{array}{l}0.114 \\
0.006\end{array}$ & $\begin{array}{l}0.134 \\
0.003\end{array}$ & $\begin{array}{l}-0.042 \\
-0.005\end{array}$ & 0.009 & $\begin{array}{l}-0.002 \\
-0.019\end{array}$ & $\begin{array}{l}-0.049 \\
-0.049\end{array}-100$ & $\begin{array}{r}0.021 \\
-0.021\end{array}$ & 0.002 & $\begin{array}{l}-0.001 \\
-0.011\end{array}$ & $\begin{array}{r}-0.012 \\
-0.013\end{array}$ & $\begin{array}{r}.0 .020 \\
-0.003\end{array}$ & $\begin{array}{l}-0.035 \\
-0.018\end{array}$ & 20 & - & - & $\begin{array}{l}0.150 \\
0.016\end{array}$ & $\begin{array}{l}-0.170 \\
-0.021\end{array} \quad-1$ & -0.007 & & $\begin{array}{l}0.022 \\
-0.011\end{array}$ & $\begin{array}{r}-0.010 \\
-0.010\end{array}$ & $\begin{array}{l}0.150 \\
0.016\end{array}$ & 0.021 \\
\hline & & & 0.1 & -0.067 & & & & 0.0 & 0.0 & & & & & & - & - & & & & & & & & 335 \\
\hline Workp & $\begin{array}{r}-0.003 \\
-\end{array}$ & 0.8 r & -0.013 & 0.0 & 0.025 & $\begin{array}{c}0.0 \\
-0.0\end{array}$ & -0.016 & 0.0 & 0.009 & -0 . & -0.005 & 0. & $\begin{array}{l}-0.050 \\
-0.050\end{array}$ & -0 & - & $=$ & 0.120 & -0.1 & .008 & & -0.008 & & 0.120 & 0.190 \\
\hline Wage residua & 0.144 & & 0.118 & & 0.119 & & 0.100 & & 0.081 & & 0.079 & & 0.083 & & 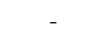 & & -0.126 & & 0.075 & & 0.103 & & -0.126 & \\
\hline Difference in inequality & 0.249 & & 0.210 & & 0.189 & & 0.131 & & 0.133 & & 0.111 & & 0.009 & & & & -0.144 & & 0.111 & & 0.147 & & -0.144 & \\
\hline & Charact. & Returns & Charact. & Returns & Charact. & Returns & Charact. & Returns & Charact. & Returns & Charact. & Returns & Charact. & Returns & Charact. & Returns & Charact. & Returns & Charact. & Returns & Charact. & Returns & Charact. & Returns \\
\hline Aggreg & -0.029 & 0.208 & 0.123 & 0.042 & 0.038 & 0.105 & -0.049 & 0.154 & 0.053 & 0.073 & -0.012 & 0.117 & Charact. & . neturns & -0.023 & 0.096 & 0.024 & 0.032 & 0.016 & & 21 & & 0.001 & 0.064 \\
\hline Ag & & & & 0.020 & & & & $\begin{array}{l}0.154 \\
0.002\end{array}$ & & & & & - & $\begin{array}{l}- \\
-\end{array}$ & & $\begin{array}{l}0.030 \\
0.039\end{array}$ & & 0.032 & & & & & & \\
\hline & & & & . & & 0 & & 0. & & & & 0 & - & - & 2 & 0.0 & & & & & & & & \\
\hline Work & $\begin{array}{l}-0.015 \\
-0.007\end{array}$ & 0.091 & 0.022 & 0.048 & 0.029 & 0.040 & 0.001 & 0.080 & 0.039 & 0.006 & 0.004 & 0.05 & $=$ & - & 0.050 & 0.003 & 0.044 & $\begin{array}{l}-0.062 \\
-0.060\end{array}$ & 0.023 & 0.032 & 0.015 & 0.053 & $\begin{array}{l}-0.047 \\
0.047\end{array}$ & -0.029 \\
\hline Wage re & 0.061 & & 0.036 & & 0.037 & & 0.018 & & -0.002 & & -0.003 & & 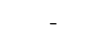 & & -0.083 & & -0.209 & & -0.018 & & 0.025 & & -0.146 & \\
\hline hequality & 0.240 & & 0.201 & & 0.180 & & 0.122 & & 0.124 & & 0.102 & & - & & -0.009 & & -0.153 & & 0.101 & & 0.162 & & -0.081 & \\
\hline (Ially & Charact. & Returns & Charact. & Returns & $\begin{array}{l}0.100 \\
\text { Charact. }\end{array}$ & Returns & Charact. & Returns & Charact. & Returns & $\begin{array}{l}0.102 \\
\text { Charact. }\end{array}$ & Returns & Charact. & Retu & Charact. & Returns & Charact. & Returns & Charact. & Returns & Charact. & Returns & $\begin{array}{l}-0.001 \\
\text { Charact. }\end{array}$ & Returns \\
\hline Aggreg & -0 & $\begin{array}{c}\text { Keturns } \\
0.075\end{array}$ & Charact. & & 0.098 . & & Charact. & & & & Charact. & Keturns & 0.018 . & & $\begin{array}{l}\text { Chatact. } \\
-0.003\end{array}$ & - Ketu & Charact. & & Charact. & & 0.050 & & $\begin{array}{c}\text { Charact. } \\
0.040\end{array}$ & \\
\hline $\mathrm{It}$ & & & & & & & & & & & 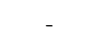 & - & & & & & & & & & & & & \\
\hline & $\begin{array}{l}-0.007 \\
-0.007\end{array}$ & 0.036 & & $\begin{array}{l}-0.068 \\
-0.068\end{array}$ & & $\begin{array}{l}-0.010 \\
-0.005\end{array}$ & 8 & 0.034 & 2 & & - & - & 0.021 & -0. & -0.040 & $\begin{array}{l}-0.007 \\
-0.007\end{array}$ & $\begin{array}{l}-0.003 \\
-0.03\end{array}$ & 0.014 & 0.012 & & 0.023 & & $\begin{array}{l}-0.007 \\
-0.007\end{array}$ & $\begin{array}{l}-0.014 \\
-0.014\end{array}$ \\
\hline eristics & 0.006 & 0.024 & 0.0 & 0.014 & 0.054 & -0.040 & 0.007 & 0.020 & 0.015 & -0.025 & - & - & -0.008 & -0.047 & 0.028 & -0.029 & 0.077 & -0.148 & 0.023 & -0.02 & 0.017 & -0.001 & 0.032 & -0.075 \\
\hline & 0.064 & & & & & & 0.021 & & 0.001 & & & & 0.00 & & -0.0 & & -0.206 & & -0.015 & & & & -0.094 & \\
\hline lity & 0.138 & & 9 & & 0. & & 0.020 & & 0.022 & & 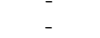 & & $\begin{array}{l}-0.102 \\
-\end{array}$ & & -0.111 & & -0.255 & & -0.014 & & 0.071 & & -0.156 & \\
\hline & Cha & $\mathrm{Re}$ & Cha & $\mathrm{R}$ & & Re & & Ret & Charact. & Returns & C & $\operatorname{Re}$ & Char & Ret & Charact. & $\operatorname{Re}$ & Charact. & & & & & & & \\
\hline$\pi$ & & & & & & & & & - & - & & & & & & & & & & & & & & \\
\hline tics & & & & & & & & & - & 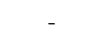 & & & & & & & 4 & & & & & & & \\
\hline & $\begin{array}{l}-0 \\
-0 \\
-1\end{array}$ & 0. & & -0. & $\begin{array}{c}0 . \\
-0 .\end{array}$ & -0. & & $\begin{array}{r}-. \\
0 .\end{array}$ & - & - & & $\begin{array}{c}.0 . \\
-0.0\end{array}$ & & & $\begin{array}{l}-0 . \\
-0 .\end{array}$ & -0.6 & & 0. & & $\begin{array}{c}0 . \\
-0 .\end{array}$ & & -0. & -0.026 & -0.013 \\
\hline W & & 0.051 & & 0.040 & & 0.033 & -0 & 0.051 & 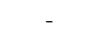 & 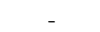 & & 0.036 & -0. & 0.029 & -0.8 & 0.026 & -0.8 & $\begin{array}{l}-0.045 \\
-\end{array}$ & -0. & 0.028 & -0.012 & 0.044 & -0.033 & 0.012 \\
\hline & & & & & & & & & - & & & & 0.0 & & -0.0 & & -0.207 & & -0.016 & & 0.040 & & -0.072 & \\
\hline Diff & 0.11 & & 0.077 & & 0.056 & & $\begin{array}{r}0.01 \\
-0.002\end{array}$ & & - & & $\begin{array}{l}-0.001 \\
-0.022\end{array}$ & & $\begin{array}{l}0.00 \\
-0.12\end{array}$ & & $\begin{array}{l}-0.0 \\
-0.1\end{array}$ & & $\begin{array}{l}-0.201 \\
-0.277\end{array}$ & & $\begin{array}{l}-0.010 \\
-0.039\end{array}$ & & $\begin{array}{l}0.040 \\
0.062\end{array}$ & & $\begin{array}{l}-0.072 \\
-0.139\end{array}$ & \\
\hline & Char & & Charact. & & Charact. & & Charact. & eturns & Chara & & Charact. & & Cha & & & & & & & & & & & \\
\hline Agg & & & & & & & - & 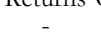 & & & & & & & & & & & & & & & & \\
\hline tics & & & & & & & - & - & & & & & & & & & & & & & & & & 0. \\
\hline & & & & & & & - & - & & & & & & & & & & & & & & & 0.040 & -0.075 \\
\hline W & -0.0 & 0.004 & -0.0 & -0.006 & 0. & -0.022 & - & - & 0.01 & -0.051 & 0.0 & -0.037 & $\begin{array}{c}-0.0 \\
-0.0\end{array}$ & -0.028 & $\begin{array}{c}-0.002 \\
-0.002\end{array}$ & -0.026 & 0.0 & $\begin{array}{l}-0.099 \\
-\end{array}$ & $\begin{array}{r}-0.003 \\
-0.003\end{array}$ & -0.033 & 0.001 & -0.008 & $\begin{array}{r}.0 .006 \\
-0.006\end{array}$ & -0.048 \\
\hline & 0.0 & & $\begin{array}{r}-0 . \\
0.8\end{array}$ & & 0. & & & & $\begin{array}{r}.0 .01 \\
-0.01\end{array}$ & & $\begin{array}{r}.0 \\
-0.0\end{array}$ & & $\begin{array}{l}-0.0 \\
-0.0\end{array}$ & & $\begin{array}{l}-0.0 \\
-0.1\end{array}$ & & $\begin{array}{l}-0.022 \\
-0.226\end{array}$ & & $\begin{array}{l}-0.0038 \\
-0.038\end{array}$ & & 0.027 & & $\begin{array}{l}-0.077 \\
-0.077\end{array}$ & \\
\hline & 0.118 & & 0.079 & & 0.058 & & & & 0.002 & & -0.020 & & -0.122 & & -0.131 & & -0.275 & & & & & & & \\
\hline & Charact. & Rets & Charact. & Ret & Charact. & Returns & Charact. & Returns & Char & Ret & Charact. & Ret & Charact. & Ret & Charact. & Returns & Charact. & Ret & Charact. & Ret & Charact. & ns & Charact. & Returns \\
\hline & & & & & - & & & & & & & & & & & & & & & & & & & \\
\hline cs & & & & & - & - & & & & & & & & & & & & & & & -0.005 & & -0.015 & 0.002 \\
\hline & .0 & 0.02 & & & 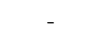 & - & -0.020 & 0.0 & 0.004 & 0.0 & -0.005 & -0.012 & & -0.040 & -0.8 & -0.0 & -0.009 & & 0.000 & -0.012 & 0.045 & -0.033 & -0.015 & -0.005 \\
\hline ristics & -0.011 & 0.027 & -0.006 & 0.008 & 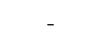 & 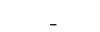 & -0.012 & 0.025 & -0.002 & -0.022 & -0.008 & -0.006 & -0.065 & -0.004 & -0.004 & -0.012 & 0.005 & $\begin{array}{l}-0.090 \\
-\end{array}$ & -0.013 & -0.009 & -0.009 & 0.018 & -0.014 & -0.018 \\
\hline & 0.0 & & -0.0 & & - & & -0.019 & & -0.039 & & -0.040 & & -0.037 & & -0.119 & & $\begin{array}{l}0.0 \\
-0.2\end{array}$ & & -0.060 & & 0.012 & & -0.083 & \\
\hline inequality & & & 0.0 & & - & & -0.058 & & -0.056 & & -0.07 & & -0.18 & & -0.1 & & -0.3 & & -0.102 & & 0.041 & & -0.149 & \\
\hline & Chara & & Charact. & & & & Charact. & & Charact. & & Charact. & & & & & & & & & & & & Charact. & \\
\hline Aggregate & -0.047 & .061 & & & -0.010 & -0.012 & -0.088 & 0.027 & 0.007 & -0.046 & -0.068 & 0.008 & -0.124 & -0.041 & -0.063 & -0.0 & -0.063 & -0.047 & -0.057 & -0.010 & -0.047 & 0.061 & -0.058 & -0.020 \\
\hline
\end{tabular}


$\begin{array}{llllllllllll}0.0 .005 & -0.007 & 0.008 & -0.007 & 0.003 & -0.015 & -0.002 & -0.014 & 0.014 & -0.015 & -0.004\end{array}$

$0.026-0.023---10$

Difference in inequality

0.039

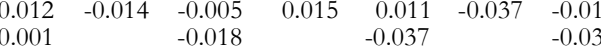

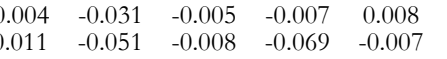

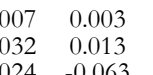

$\begin{array}{rrr}-0.015 & -0.002 & -0.014 \\ -0.035 & 0.009 & -0.024 \\ -0.008 & -0.017 & -0.009\end{array}$

$\begin{array}{rrr}0.014 & -0.015 & -0.004 \\ 0.024 & -0.036 & 0.007\end{array}$

Reference: Norway

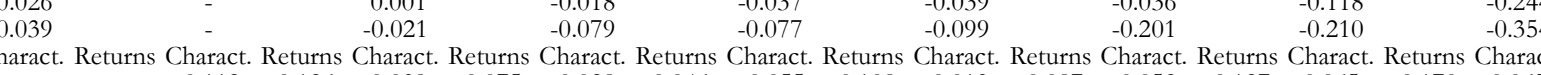

$\begin{array}{llll}-0.058 & 0.026 & -0.070 \\ -0.125 & 0.039 & -0.149\end{array}$

goregate
Individual characteristics

Job characteristics

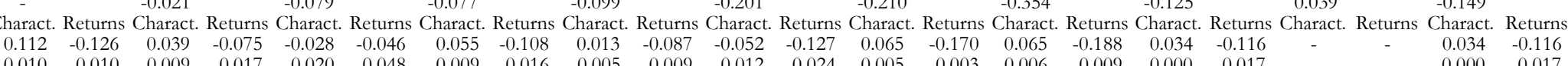

ract. Returns Charact. Returns Charact. Returns Charact.

Returns

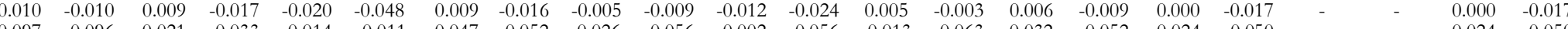
\begin{tabular}{llllllllllllllllll} 
& 0.024 & -0.050 \\
\hline
\end{tabular}

Wage residuals

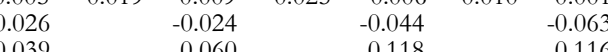

$-0.064$

$-0.061$

-0.144
-0.249

-0.270
-0.393

0.024
-0.087
-0.169

$-0.087$ 


\section{Appendix}

Table A.1

Descriptive evidence and regression results.

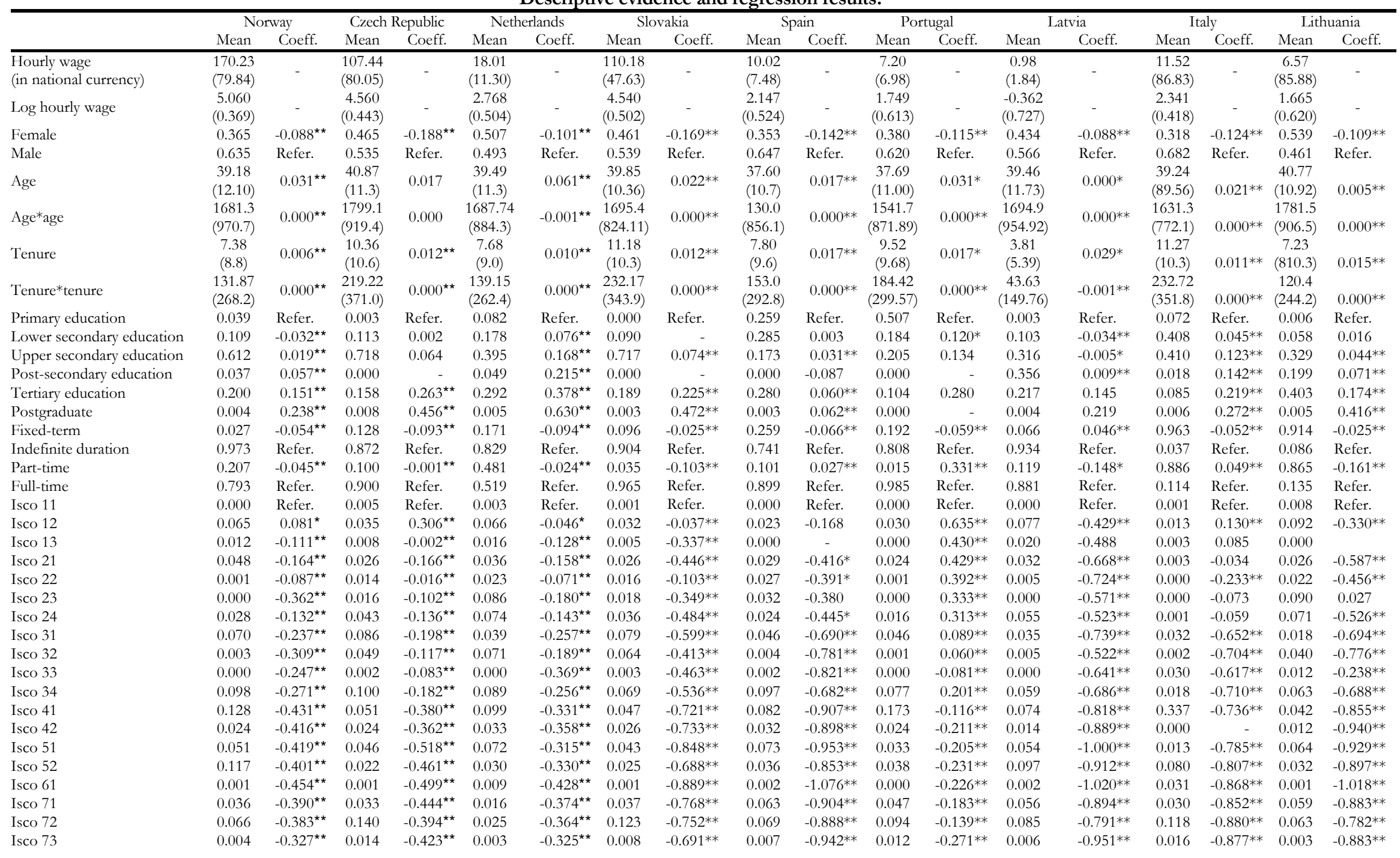




\begin{tabular}{|c|c|c|c|c|c|}
\hline Isco 74 & 0.014 & $-0.415^{\star \star}$ & 0.024 & $-0.453^{\star \star}$ & 0.004 \\
\hline Isco 81 & 0.041 & $-0.337^{\star \star}$ & 0.057 & $-0.390^{\star *}$ & 0.007 \\
\hline Isco 82 & 0.055 & $-0.423^{\star \star}$ & 0.077 & $-0.400^{\star \star}$ & 0.016 \\
\hline Isco 83 & 0.037 & $-0.464^{\star \star}$ & 0.061 & $-0.432^{\star \star}$ & 0.020 \\
\hline Isco 91 & 0.043 & $-0.473^{\star \star}$ & 0.029 & $-0.618^{\star \star}$ & 0.055 \\
\hline Isco 92 & 0.001 & $-0.442^{\star *}$ & 0.000 & $-0.638^{\star \star}$ & 0.000 \\
\hline Isco 93 & 0.018 & $-0.467^{* *}$ & 0.034 & $-0.573^{\star \star}$ & 0.022 \\
\hline Isco 99 & 0.040 & $-0.327^{\star \star}$ & 0.000 & 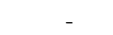 & 0.084 \\
\hline Size $10-49$ & 0.172 & Refer. & 0.012 & Refer. & 0.026 \\
\hline Size $50-249$ & 0.256 & 0.029 & 0.100 & $0.065^{\star \star}$ & 0.153 \\
\hline Size $250-499$ & 0.143 & 0.032 & 0.121 & $0.080^{\star \star}$ & 0.140 \\
\hline Size 500-999 & 0.127 & $0.031^{*}$ & 0.162 & $0.102^{\star \star}$ & 0.105 \\
\hline Size $>999$ & 0.301 & $0.040^{\star \star}$ & 0.604 & $0.126^{\star \star}$ & 0.576 \\
\hline Publicly owned firm & 0.868 & $-0.039^{\star \star}$ & 0.616 & $0.029^{\star \star}$ & 0.447 \\
\hline Other type of control & 0.132 & Refer. & 0.384 & Refer. & 0.553 \\
\hline Nace division 10 & 0.000 & $0.058^{\star \star}$ & 0.032 & $0.279^{\star \star}$ & 0.000 \\
\hline Nace division 11 & 0.036 & $0.282^{\star \star}$ & 0.000 & $-0.035^{\star \star}$ & 0.002 \\
\hline Nace division 12 & 0.000 & & 0.004 & $0.124^{\star \star}$ & 0.000 \\
\hline Nace division 13 & 0.001 & $0.049^{\star \star}$ & 0.000 & & 0.000 \\
\hline Nace division 14 & 0.003 & 0.005 & 0.001 & $0.228^{\star \star}$ & 0.000 \\
\hline Nace division 15 & 0.058 & $-0.073^{\star \star}$ & 0.033 & $0.053^{\star \star}$ & 0.012 \\
\hline Nace division 16 & 0.001 & -0.057 & 0.001 & $0.492^{\star \star}$ & 0.001 \\
\hline Nace division 17 & 0.004 & -0.126 & 0.030 & $0.070^{\star \star}$ & 0.001 \\
\hline Nace division 18 & 0.001 & -0.197 & 0.008 & $0.012^{\star \star}$ & 0.000 \\
\hline Nace division 19 & 0.001 & -0.118 & 0.003 & $0.078^{\star}$ & 0.000 \\
\hline Nace division 20 & 0.012 & -0.169 & 0.005 & $0.035^{\star \star}$ & 0.000 \\
\hline Nace division 21 & 0.012 & $-0.094^{\star \star}$ & 0.006 & 0.141 & 0.003 \\
\hline Nace division 22 & 0.020 & $-0.005^{\star \star}$ & 0.003 & $0.181^{\star \star}$ & 0.009 \\
\hline Nace division 23 & 0.002 & $0.075^{\star *}$ & 0.003 & $0.226^{\star \star}$ & 0.001 \\
\hline Nace division 24 & 0.020 & $-0.008^{\star *}$ & 0.016 & 0.095 & 0.014 \\
\hline Nace division 25 & 0.006 & -0.103 & 0.020 & 0.145 & 0.003 \\
\hline Nace division 26 & 0.010 & -0.069 & 0.034 & $0.126^{\star \star}$ & 0.003 \\
\hline Nace division 27 & 0.018 & $-0.015^{\star \star}$ & 0.038 & $0.179^{\star \star}$ & 0.004 \\
\hline Nace division 28 & 0.011 & $-0.092^{\star \star}$ & 0.021 & $0.040^{\star \star}$ & 0.005 \\
\hline Nace division 29 & 0.016 & $-0.031^{\star \star}$ & 0.052 & -0.028 & 0.007 \\
\hline Nace division 30 & 0.000 & $-0.065^{\star \star}$ & 0.002 & $-0.191^{*}$ & 0.001 \\
\hline Nace division 31 & 0.008 & $-0.030^{\star \star}$ & 0.030 & $0.052^{\star \star}$ & 0.003 \\
\hline Nace division 32 & 0.006 & $-0.088^{\star \star}$ & 0.013 & $0.034^{\star \star}$ & 0.012 \\
\hline Nace division 33 & 0.005 & $0.008^{\star \star}$ & 0.008 & $-0.024^{*}$ & 0.002 \\
\hline Nace division 34 & 0.006 & $-0.074^{\star}$ & 0.049 & 0.195 & 0.004 \\
\hline Nace division 35 & 0.026 & -0.045 & 0.010 & $0.035^{\star}$ & 0.004 \\
\hline Nace division 36 & 0.008 & $-0.057^{\star \star}$ & 0.012 & 0.054 & 0.027 \\
\hline Nace division 37 & 0.001 & -0.053 & 0.001 & 0.070 & 0.000 \\
\hline Nace division 40 & 0.021 & $-0.085^{\star *}$ & 0.029 & $0.204^{\star \star}$ & 0.007 \\
\hline Nace division 41 & 0.000 & & 0.013 & $0.054^{\star \star}$ & 0.001 \\
\hline Nace division 45 & 0.067 & Refer. & 0.033 & Refer. & 0.020 \\
\hline Nace division 50 & 0.023 & $-0.057^{\star \star}$ & 0.004 & 0.082 & 0.006 \\
\hline Nace division 51 & 0.073 & -0.030 & 0.010 & $0.036^{\star \star}$ & 0.026 \\
\hline Nace division 52 & 0.125 & $-0.137^{\star \star}$ & 0.044 & $-0.106^{\star \star}$ & 0.068 \\
\hline Nace division 55 & 0.057 & $-0.074^{\star \star}$ & 0.010 & $0.044^{\star \star}$ & 0.008 \\
\hline Nace division & & $-0.0 \quad-\quad>$ & 0.074 & 0.136 & \\
\hline
\end{tabular}

$\begin{array}{llllllll}-0.343^{* *} & 0.040 & -0.770 * * & 0.023 & -0.979 * * & 0.084 & -0.297 * * & 0.073\end{array}$ $\begin{array}{llllllll}-0.273^{* *} & 0.069 & -0.724 * * & 0.028 & -0.897 * * & 0.028 & -0.199 * * & 0.032\end{array}$ $\begin{array}{llllllll}-0.369^{* *} & 0.073 & -0.749 * * & 0.119 & -0.941 * * & 0.093 & -0.238 * * & 0.030\end{array}$ $\begin{array}{llllllll}-0.362^{* *} & 0.084 & -0.717 * * & 0.054 & -0.923^{* *} & 0.057 & -0.177 * * & 0.082\end{array}$ $\begin{array}{llllllll}-0.456^{* *} & 0.035 & -0.964 * * & 0.067 & -1.057 * * & 0.055 & -0.379 * * & 0.061\end{array}$ $\begin{array}{llllllll}-0.463^{* *} & 0.000 & -1.128 * * & 0.001 & -1.047 * * & 0.000 & - & 0.001\end{array}$ $\begin{array}{llllllll}-0.401 * * & 0.040 & -0.854 * * & 0.063 & -1.014 * * & 0.068 & -0.350 * * & 0.045\end{array}$ $\begin{array}{llllll}0.361^{* *} & 0.000-0.000 & - & - & 0.000 & -0.000\end{array}$

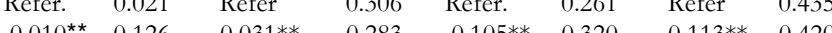
$\begin{array}{llllllll}0.010^{* *} & 0.126 & 0.031^{* *} & 0.283 & 0.105^{* *} & 0.320 & 0.113^{* *} & 0.420 \\ 0.01 *^{*} & 0.116 & 0.08 * * & 0.097 & 0.157^{* *} & 0.104 & 0.205 * * & 0.062\end{array}$

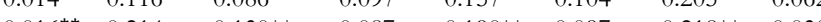
$0.016=0.214-0.130 *-0.087-0.190 * 0.097-0.218 * 0.030$ $\begin{array}{llllllll}0.032^{* *} & 0.524 & 0.152 * * & 0.227 & 0.199 * * & 0.218 & 0.231 * * & 0.053\end{array}$

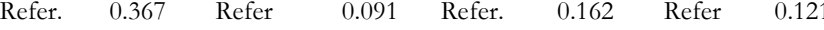
$\begin{array}{llll}0.206 * * & 0.003 & 0.359 * * & 0.000\end{array}$$$
\begin{array}{cc}
- & 0.006 \\
- & 0.000 \\
-0.028 * * & 0.000
\end{array}
$$

$\begin{array}{lllll}-0.900 * * & 0.067 & -0.907 * * & 0.031 & -0.865 * *\end{array}$

$\begin{array}{lllll}-0.850 * * & 0.012 & -0.818 * * & 0.019 & -0.862 * *\end{array}$

$\begin{array}{llllll}-0.766 * * & 0.084 & -0.904 * * & 0.056 & -0.786 * *\end{array}$

$\begin{array}{llll}-0.855 * * & 0.000 & 0.065 & -0.850 * *\end{array}$

$\begin{array}{lllll}-1.081 * * & 0.061 & -0.923 * * & 0.089 & -1.111 * *\end{array}$

$\begin{array}{lllll}-0.872 * * & 0.001 & -0.849 * * & 0.001 & -0.972 * *\end{array}$

$\begin{array}{lllll}-0.863 * * & 0.048 & -0.890 * * & 0.021 & -0.981 * *\end{array}$ $\begin{array}{lll}- & 0.000-0.000\end{array}$

$\begin{array}{llllll}0.201 & 0.204 & 0.099 * * & 0.446 & \text { Refer } \\ 0.408 & 0.155 & 0.157 * & 0.119 & 0.237 * *\end{array}$ $\begin{array}{llllll}0.201 & 0.204 & 0.099 * * & 0.446 & 0.156^{* *} \\ 0.408 & 0.155 & 0.157 * * & 0.119 & 0.237^{*}\end{array}$ $\begin{array}{lllll}0.390 & 0.113 & 0.188 * * & 0.119 & 0.237 *\end{array}$ $0.409=0.231-0.181 * 0.128=0.30 \%$ $\begin{array}{lllll}0.409 & 0.231 & 0.181^{* *} & 0.128 & 0.309 * * \\ 0.128^{* *} & 0.919 & 0.022 * * & 0.503 & 0.153 *\end{array}$ $\begin{array}{llll}0.059 & \text { Refer } 0.497 \quad \text { Refer }\end{array}$ $\begin{array}{rrrrr}0.381 & 0.000 & -0.262 * * & 0.002 & 0.111 * * \\ - & 0.000 & 0.367 * & 0.001 & 1.035 *\end{array}$ $0.000-0.000$ $\begin{array}{lll}0.000-0.000 & - & 0 \\ 0.010 & 0.015 & 0.002\end{array}$

$\begin{array}{lllll}0.466 & 0.010 & 0.015 & 0.002 & 0.289 * *\end{array}$ $\begin{array}{lllll}0.036 * * & 0.040 & 0.024 * * & 0.052 & -0.007\end{array}$ $\begin{array}{lllll} & 0.001 & -0.023 & 0.001 & 1.011^{* *} \\ 0.086 * * & 0.030 & -0.040 * * & 0.017 & 0.095 *\end{array}$ $\begin{array}{llllll}0.050 * * & 0.018 & -0.080 * * & 0.041 & -0.070 * *\end{array}$ $\begin{array}{llllll}-0.059 * * & 0.015 & -0.090 * * & 0.003 & -0.066 * *\end{array}$ $\begin{array}{llllll}-0.067 * * & 0.017 & -0.120 * * & 0.019 & -0.104 * *\end{array}$ $\begin{array}{lllll}-0.016 * * & 0.018 & 0.041 * * & 0.003 & 0.209 * *\end{array}$ $\begin{array}{lllll}0.080 * * & 0.019 & 0.079 * * & 0.009 & -0.013\end{array}$ $\begin{array}{llll}0.009 & 0.136^{* *} & 0.001 & 0.814^{* *}\end{array}$ $\begin{array}{lllll}0.004 & 0.039 & 0.056^{* *} & 0.005 & 0.185^{* *}\end{array}$ $\begin{array}{lllll}0.024 * * & 0.027 & 0.000 & 0.007 & 0.027 \\ 0.195 * * & 0.038 & 0.028 * * & 0.009 & 0.093 *\end{array}$ $\begin{array}{lllll}-0.02 * * & 0.027 & 0.000 & 0.007 & 0.027 \\ 0.173^{*} & 0.038 & 0.028^{* *} & 0.009 & 0.099^{*} \\ 0.173^{*} & 0.026 & 0.052^{* *} & 0.002 & 0.010 *\end{array}$ $\begin{array}{lllll}0.173 * & 0.026 & 0.052^{* *} & 0.002 & 0.083 * * \\ 0.100^{* *} & 0.029 & -0.007 & 0.011 & -0.101^{*}\end{array}$ $\begin{array}{lllll}0.100 * * & 0.029 & -0.007 & 0.011 & -0.101 *\end{array}$ $\begin{array}{ccccc}-0.010^{* *} & 0.065 & 0.020^{* *} & 0.010 & -0.003 \\ 0.177^{* *} & 0.006 & -0.012 & 0.000 & -0.373 *\end{array}$ $\begin{array}{lllll}0.177^{* *} & 0.006 & -0.012 & 0.000 & -0.373^{* *}\end{array}$ $\begin{array}{ccccc}0.141^{* *} & 0.028 & -0.022^{*} & 0.004 & 0.142^{*}\end{array}$ $\begin{array}{lllll}0.0 .090^{* *} & 0.019 & -0.014 & 0.005 & 0.010\end{array}$ $\begin{array}{llllll}-0.061 * * & 0.017 & -0.005 & 0.004 & 0.053^{*}\end{array}$ $\begin{array}{lllll}0.057 * * & 0.036 & 0.030^{* *} & 0.001 & -0.039\end{array}$ $\begin{array}{llllll}0.040^{* *} & 0.019 & -0.035^{* *} & 0.008 & 0.231 * *\end{array}$ $\begin{array}{lllll}0.016^{* *} & 0.022 & -0.116 * * & 0.015 & -0.053^{* *}\end{array}$ $\begin{array}{llllll}-0.034 * * & 0.006 & -0.011 & 0.002 & -0.094 * *\end{array}$ $\begin{array}{lllll}0.162 & 0.019 & 0.060 * * & 0.020 & 0.040^{* *}\end{array}$ $\begin{array}{lllll}0.114 * * & 0.006 & 0.092 * * & 0.008 & -0.052 * *\end{array}$ $\begin{array}{lllll}\text { Refer* } & 0.026 & \text { Refer } & 0.075 & \text { Refer }\end{array}$ $\begin{array}{lllll}-0.018 * * & 0.017 & 0.003 & 0.020 & -0.107 * *\end{array}$ $\begin{array}{llllll}0.062 * * & 0.034 & 0.001 & 0.036 & -0.028 * *\end{array}$ $\begin{array}{lllll}-0.123 * * & 0.049 & -0.089 * * & 0.044 & -0.123 * *\end{array}$ $\begin{array}{lllll}0.103 * * & 0.023 & -0.131 * * & 0.013 & -0.089 * *\end{array}$ $\begin{array}{lllll}-0.031 * * & 0.036 & -0.062 * * & 0.038 & -0.137 * *\end{array}$ 


\begin{tabular}{|c|c|c|c|c|c|c|c|c|c|c|c|c|c|c|c|c|c|c|}
\hline Nace division 61 & 0.018 & -0.031 & 0.000 & & 0.001 & $0.085^{\star *}$ & 0.001 & $0.299 * *$ & 0.001 & $0.086^{* *}$ & 0.003 & $0.272^{* *}$ & 0.001 & 0.415 & 0.005 & $0.116^{* *}$ & 0.003 & $0.220^{* *}$ \\
\hline Nace division 62 & 0.020 & $0.128^{\star \star}$ & 0.004 & $0.469^{\star \star}$ & 0.007 & $0.085^{\star \star}$ & 0.001 & $0.337 * *$ & 0.002 & $0.212^{* *}$ & 0.017 & $0.328 * *$ & 0.002 & 0.209 & 0.004 & $0.283 * *$ & 0.001 & $0.262^{* *}$ \\
\hline Nace division 63 & 0.018 & $-0.039^{\star *}$ & 0.008 & $0.205^{\star \star}$ & 0.008 & $0.040^{\star \star}$ & 0.003 & $0.133^{* *}$ & 0.014 & -0.006 & 0.017 & $0.326 * *$ & 0.035 & $0.319^{* *}$ & 0.026 & $0.042 * *$ & 0.012 & $0.207 * *$ \\
\hline Nace division 64 & 0.063 & $-0.039^{\star *}$ & 0.046 & $0.115^{\star \star}$ & 0.030 & $-0.060^{\star \star}$ & 0.048 & $0.132 * *$ & 0.011 & $-0.036 * *$ & 0.018 & $0.289 * *$ & 0.031 & $0.119 * *$ & 0.009 & $0.051 * *$ & 0.016 & 0.011 \\
\hline Nace division 65 & 0.050 & $-0.085^{\star \star}$ & 0.031 & $0.021^{\star \star}$ & 0.033 & $0.123^{\star \star}$ & 0.016 & $0.565^{* *}$ & 0.036 & $0.160^{* *}$ & 0.107 & $0.305 * *$ & 0.015 & 0.344 & 0.059 & $0.305^{* *}$ & 0.013 & $0.405^{* *}$ \\
\hline Nace division 66 & 015 & $-0.104^{\star \star}$ & 0.009 & $0.066^{\star \star}$ & 0.013 & $076^{\star \star}$ & 0.008 & $0.216^{* *}$ & 0.011 & $.078 * *$ & 0.004 & $0.358 * *$ & 0.004 & 0.227 & 0.015 & $0.177 * *$ & 0.006 & $0.220 * *$ \\
\hline ion 70 & 008 & $-0.019^{\star \star}$ & 0.008 & $0.085^{\star \star}$ & 0.005 & $.086^{\star \star}$ & 0.004 & $0.226^{* *}$ & 0.002 & $0.066^{* *}$ & 0.005 & $-0.001 * *$ & 0.046 & 4 & 0.006 & 0.023 & 0.012 & $0.073 * *$ \\
\hline Nace c & 004 & $-0.040^{\star}$ & 0.000 & $0.358^{\star \star}$ & 0.001 & $-0.074^{\star \star}$ & 0.000 & $0.112^{* *}$ & .002 & $-0.086^{* *}$ & 0.010 & $0.043 * *$ & 0.003 & $8 * *$ & 0.005 & 0.020 & 0.000 & $0.156^{* *}$ \\
\hline on 72 & 032 & $0.066^{*}$ & 0.001 & $-0.069^{\star *}$ & 0.011 & $-0.033^{\star \star}$ & 0.004 & $0.613^{* *}$ & 0.005 & $-0.139 * *$ & 0.012 & $0.088 * *$ & 0.010 & $.179 * *$ & 0.024 & $0.020^{*}$ & 0.004 & $0.109 * *$ \\
\hline Nace & 010 & $-0.146^{\star}$ & 0.006 & $-0.154^{\star \star}$ & 0.006 & $-0.036^{\star \star}$ & 0.009 & $0.018^{* *}$ & .001 & $-0.227 * *$ & 0.003 & $0.135 * *$ & 0.009 & $0.800 * *$ & 0.005 & 0.008 & 0.007 & $-0.408 * *$ \\
\hline n 74 & 064 & $-0.045^{\star *}$ & 0.029 & $-0.116^{\star \star}$ & 0.082 & $-0.031^{\star \star}$ & 0.014 & $0.043^{* *}$ & 0.078 & $-0.108 * *$ & 0.040 & $0.153 * *$ & 0.045 & 135 ** & 0.069 & $-0.152^{* *}$ & 0.024 & 0.001 \\
\hline 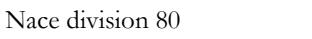 & 000 & - & 0.029 & $-0.272^{\star *}$ & 0.130 & $003^{\star \star}$ & 0.036 & $-0.109 * *$ & 1 & $-0.176^{* *}$ & 0.000 & - & 0.000 & - & 0.000 & - & 0.183 & $22^{* *}$ \\
\hline & 00 & - & 0.099 & $0.013^{\star *}$ & 0.248 & $044^{\star \star}$ & 0.122 & $-0.017 * *$ & 0.067 & -0 . & 0.00 & - & 0.1 & - & 0.000 & - & 0.100 & 3 3* \\
\hline n 90 & 000 & - & 0.009 & $0.032^{\star *}$ & 0.004 & $64^{\star \star}$ & 0.004 & 0.0 & 0.008 & 2** & 0.000 & - & 0.1 & - & 0.000 & - & 0.013 & $32 * *$ \\
\hline Nace & 00 & - & 0.000 & $-0.172^{\star *}$ & 0.008 & $-0.043^{\star \star}$ & 0.001 & $-0.643 * *$ & 0.010 & $6^{* *}$ & 0 & - & 0. & - & 0.000 & - & 0.002 & $0.135 * *$ \\
\hline 2 & 000 & - & .01 & $-0.188^{\star \star}$ & 0.008 & & 0.004 & -0.0 & & & 0 & - & 0 & - & 0 & - & 0.025 & $-0.310 * *$ \\
\hline Nace division 93 & 0.000 & - & 0.001 & $0.057^{\star \star}$ & 0.002 & $-0.060^{\star \star}$ & 0.004 & $0.113^{* *}$ & 0.006 & $-0.171 * *$ & 0.000 & - & 0.000 & 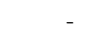 & 0.000 & 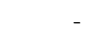 & 0.004 & $-0.075^{* *}$ \\
\hline es & $\begin{array}{l}0.365 \\
(0.21)\end{array}$ & -0 & $\begin{array}{l}0.465 \\
(0.26)\end{array}$ & $-0.294^{\star \star}$ & $\begin{array}{l}0.507 \\
(0.30)\end{array}$ & $9^{\star *}$ & $\begin{array}{l}0.461 \\
(0.24)\end{array}$ & -( & $\begin{array}{l}0.353 \\
(0.30)\end{array}$ & $-0.114 * *$ & $\begin{array}{l}0.380 \\
(0.31)\end{array}$ & * & $\begin{array}{l}0.434 \\
(0.26)\end{array}$ & * & $\begin{array}{l}0.318 \\
(0.25)\end{array}$ & $46^{* *}$ & $\begin{array}{l}0.539 \\
(80.29)\end{array}$ & ** \\
\hline Average age & $\begin{array}{l}39.18 \\
(4.7)\end{array}$ & 0. & $\begin{array}{l}40.88 \\
(3.4)\end{array}$ & $-0.018^{\star *}$ & $\begin{array}{c}39.49 \\
(5.8)\end{array}$ & $0.001^{\star *}$ & $\begin{array}{c}39.85 \\
(2.9)\end{array}$ & * & 37.6 & $0.003^{* *}$ & $\begin{array}{l}37.69 \\
(6.2)\end{array}$ & $04 * *$ & $\begin{array}{l}39.46 \\
(5.3)\end{array}$ & $-0.009 * *$ & $\begin{array}{l}39.24 \\
(4.9)\end{array}$ & 00 & $\begin{array}{c}40.77 \\
(4.6)\end{array}$ & $-0.009 * *$ \\
\hline Averagc & $\begin{array}{l}7.38 \\
(47)\end{array}$ & -0.0 & $\begin{array}{c}10.36 \\
(5.3)\end{array}$ & $05^{\star \star}$ & $\begin{array}{l}7.68 \\
(4.7)\end{array}$ & $0.002^{\star *}$ & $\begin{array}{l}11.18 \\
(5.0)\end{array}$ & ** & 7.80 & $03 * *$ & $\begin{array}{l}9.52 \\
(6.6)\end{array}$ & $-0.003^{* *}$ & 3.81 & $21 * *$ & $\begin{array}{l}11.27 \\
(5.5)\end{array}$ & 0.0 & & $0.006 * *$ \\
\hline Share low-educated workers & $\begin{array}{l}0.147 \\
(0.09)\end{array}$ & $-0.083^{\star \star}$ & $\begin{array}{c}0.116 \\
(0.098)\end{array}$ & $-0.117^{\star *}$ & $\begin{array}{l}0.259 \\
(0.23)\end{array}$ & $-0.134^{\star \star}$ & $\begin{array}{l}0.090 \\
(0.07)\end{array}$ & $-0.086^{* *}$ & $\begin{array}{l}0.543 \\
(0.35)\end{array}$ & $-0.089 * *$ & $\begin{array}{l}0.691 \\
(0.30)\end{array}$ & $-0.178^{* *}$ & $\begin{array}{l}0.106 \\
(0.14)\end{array}$ & $0.132^{* *}$ & $\begin{array}{l}0.480 \\
(0.31)\end{array}$ & $-0.065 * *$ & $\begin{array}{l}0.064 \\
(0.09)\end{array}$ & 0.079 ** \\
\hline $\mathrm{R}^{2}$ & & 0.621 & & 0.613 & & 0.62 & & 0. & & 0.5 & & 0.7 & & 0.3 & & 0.560 & & 0.493 \\
\hline & & 0.62 & & 0.6 & & & & 0.5 & & 05 & & 0.7 & & 03 & \multirow{3}{*}{\multicolumn{2}{|c|}{$\begin{array}{c}80,880 \\
8,778\end{array}$}} & & 0.493 \\
\hline $\mathrm{Nu}$ & \multirow{2}{*}{\multicolumn{2}{|c|}{566,812}} & \multirow{2}{*}{\multicolumn{2}{|c|}{$\begin{array}{c}972,729 \\
2,74\end{array}$}} & \multirow{2}{*}{\multicolumn{2}{|c|}{78,215}} & \multirow{2}{*}{\multicolumn{2}{|c|}{392,329}} & \multirow{2}{*}{\multicolumn{2}{|c|}{$\begin{array}{c}214,911 \\
21,615\end{array}$}} & \multirow{2}{*}{\multicolumn{2}{|c|}{$\begin{array}{c}58,049 \\
6,604\end{array}$}} & \multirow{2}{*}{\multicolumn{2}{|c|}{$\begin{array}{c}177,891 \\
5,023\end{array}$}} & & & \multirow{2}{*}{\multicolumn{2}{|c|}{$\begin{array}{c}137,233 \\
5,601\end{array}$}} \\
\hline Number of establishments & & & & & & & & & & & & & & & & & & \\
\hline
\end{tabular}

Number of establishments $\quad 7,491 \quad \frac{2,274}{\text { Notes: In the case of continuous variables standard deviation is in parenthesis. } * \rho<0.01 ; * *} \rho<0.05$. 
Table A.2

Earnings inequality in Europe (EU-25 plus Norway).

ESES 2002.

\begin{tabular}{|c|c|c|c|}
\hline Country & $90-10$ & $50-10$ & $90-50$ \\
\hline Finland & 1.96 & 1.32 & 1.48 \\
\hline Norway & 1.98 & 1.30 & 1.52 \\
\hline Sweden & 2.03 & 1.27 & 1.59 \\
\hline Denmark & 2.14 & 1.34 & 1.60 \\
\hline Italy & 2.46 & 1.38 & 1.78 \\
\hline Belgium & 2.62 & 1.59 & 1.64 \\
\hline Greece & 2.63 & 1.47 & 1.75 \\
\hline Netherlands & 2.75 & 1.57 & 1.75 \\
\hline Czech Republic & 2.80 & 1.63 & 1.71 \\
\hline Austria & 3.03 & 1.54 & 1.95 \\
\hline Cyprus & 3.11 & 1.58 & 1.94 \\
\hline Spain & 3.15 & 1.58 & 1.96 \\
\hline Germany & 3.15 & 1.78 & 1.78 \\
\hline United Kingdom & 3.16 & 1.59 & 1.97 \\
\hline Slovakia & 3.21 & 1.66 & 1.93 \\
\hline Portugal & 3.32 & 1.51 & 2.21 \\
\hline France & 3.36 & 1.64 & 2.00 \\
\hline Luxembourg & 3.40 & 1.76 & 1.99 \\
\hline Hungary & 3.40 & 1.63 & 2.05 \\
\hline Ireland & 3.91 & 1.78 & 2.17 \\
\hline Slovenia & 4.50 & 2.09 & 2.08 \\
\hline Latvia & 4.55 & 1.91 & 2.37 \\
\hline Poland & 4.67 & 1.99 & 2.27 \\
\hline Lithuania & 4.76 & 1.69 & 2.82 \\
\hline Estonia & 4.94 & 2.20 & 2.22 \\
\hline
\end{tabular}

Notes: Eurostat (2005). 90-10 differential, 50-10 differential and 90-50 differential are the ratios of the 10th, 50th and 90th deciles of the wage distribution. 